\title{
Bats of the BLM Billings Field Office in south-central \\ Montana, with Emphasis on the \\ Pryor Mountains
}

Prepared for:

Bureau of Land Management

Billings Field Office

5001 Southgate Drive

PO Box 36800

Billings, MT 59107

By:

Paul Hendricks, Coburn Currier, and John Carlson

Montana Natural Heritage Program

Natural Resource Information System

Montana State Library

April 2004

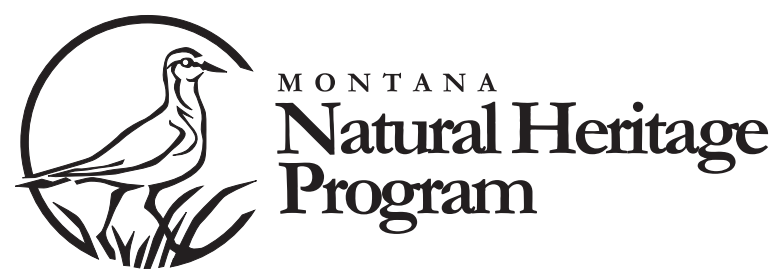




\title{
Bats of the BLM Billings Field Office in south-central \\ Montana, with Emphasis on the Pryor Mountains
}

Prepared for:

\author{
Bureau of Land Management \\ Billings Field Office5001 Southgate Drive \\ PO Box 36800 \\ Billings, MT 59107 \\ Agreement Number: \\ 1422E930A960015
}

By:

Paul Hendricks, Coburn Currier, and John Carlson
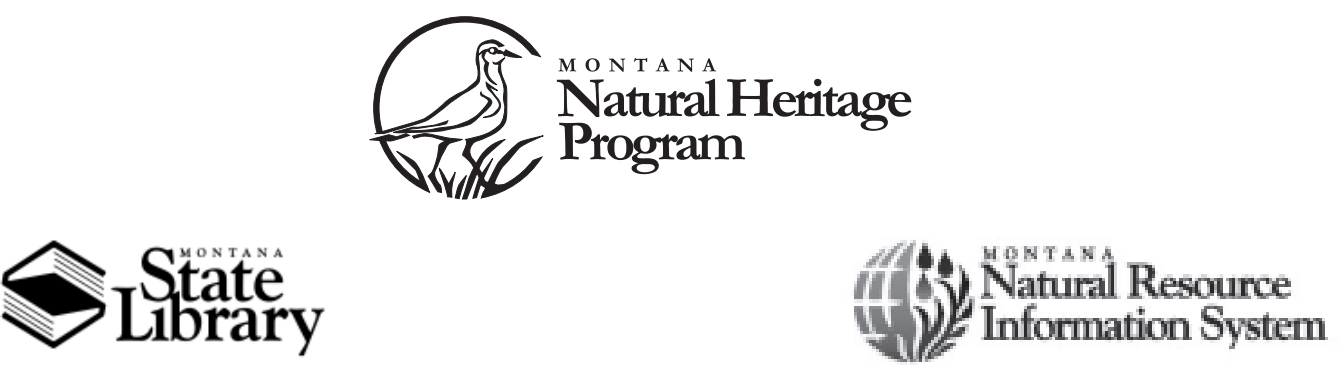

(c) 2004 Montana Natural Heritage Program

P.O. Box $201800 \bullet 1515$ East Sixth Avenue • Helena, MT 59620-1800 • 406-444-5354 
This document should be cited as follows:

Hendricks, P., C. Currier, and J. Carlson. 2004. Bats of the BLM Billings Field Office in south-central Montana, with Emphasis on the Pryor Mountains. Report to Bureau of Land Management Billings Field Office. Montana Natural Heritage Program, Helena, MT. 19 pp. + appendices. 


\section{Executive Summary}

The Bureau of Land Management (BLM) Billings Field Office harbors the greatest diversity of bat species in Montana, including three species listed as Sensitive by the BLM or Species of Concern by the Montana Natural Heritage Program and the Department of Fish, Wildlife and Parks: Pallid Bat (Antrozous pallidus), Spotted Bat (Euderma maculatum), and Townsend's Big-eared Bat (Corynorhinus townsendii).

The most recent significant survey of bats in the Billings Field Office was undertaken in the summers of 1989-1990, with a lesser survey of potential hibernacula in winter 1992. The three priority species were detected during the summer surveys, and Townsend's Big-eared Bat was detected in winter. A decade has passed with no additional bat surveys to determine the continued presence of the three species of conservation concern, nor have there been additional general surveys of bats in the Billings Field Office area.

We undertook general bat surveys during 20012003 of selected areas in the Billings Field Office area with two primary objectives: 1 ) document the continued presence of the bat species of conservation concern, and 2) document more widely the distribution and habitat associations of all bat species at selected areas of the Billings Field Office. Our work focused on the southwestern slopes of the Pryor Mountains, Carbon County, with a preliminary survey of the Bull Mountains near Roundup, Musselshell County.

We captured or observed 150 individual bats of eight species during 21 nights of netting: Pallid Bat (1); Townsend's Big-eared Bat (8); Big Brown
Bat, Eptesicus fuscus (13); Hoary Bat, Lasiurus cinereus (1); Western Small-footed Myotis, Myotis ciliolabrum (32); Western Long-eared Myotis, Myotis evotis (80); Little Brown Myotis, Myotis lucifugus (6); and Long-legged Myotis, Myotis volans (9). A Pallid Bat was captured at the site along the base of the Pryor Mountains where the species was first discovered in Montana in 1978, Townsend's Big-eared Bats were captured at two caves in the Pryor Mountains where the species was reported in 1990, at a new canyon site in the Pryor Mountains, and at a new bluff site in the Bull Mountains. In addition, we heard or recorded vocalizations of Spotted Bat at nine netting sites, including one location in the Bull Mountains. We detected all of the above species in the Pryor Mountains, and three species (Spotted Bat, Townsend's Big-eared Bat, Western Long-eared Myotis) in the Bull Mountains.

Water sources and mines or caves continue to be important habitat features for bats, particularly in the Pryor Mountains, even though few of these sites are currently protected from human disturbance. Given the significance of the Pryor Mountains area for bats, we suggest that 1) a comprehensive bat conservation plan for the Pryor Mountains be developed to guide future management activity affecting bats and bat habitat, preferably in coordination with the Custer National Forest and possibly the Bighorn Canyon National Recreation Area, and 2) additional surveys for bats be undertaken on BLM lands in the Bull Mountains and along the Yellowstone River corridor to identify the habitat associations and relative importance of these areas for the bat fauna of the BLM's Billings Field Office. 


\section{ACKNOWLEDGeMents}

We are particularly grateful to Jay Parks (BLM) for his continued interest and support of our bat inventory efforts in the BLM Billings Field Office region; the work described in this report was funded primarily through Challenge Cost Share Agreement No. 1422E930A960015 between the BLM and TNC's Montana Natural Heritage Program (MNHP). We also benefited in 2001 from DEQ Agreement 480008 Task Order No. 1 (supervised by Vic Anderson and Jack Yates) from the Montana Department of Environmental Quality to survey abandoned mines in the Pryor Mountains. We thank Joseph Johnson, summer intern with MNHP in 2003, especially for his efforts in recording and interpreting bat vocalizations. Barbara Jaquith, Joseph Johnson, Doug Keinath, Julie Mao, Bill Pryor, Erin Riley, Dustin Rogers, and Steve Schlang all participated in the netting sessions on one or more nights. Dave Worthington shared his file of bats marked in the Pryor Mountains in 1990, and Dennis Flath provided his data for bats captured at Gyp Spring in 1976 and 1978. We extend a special thanks to Bette Lowery for her hospitality and interest in the bats of her ranch, and to Burt Williams for arranging our meeting with Bette. For help in production of this report we thank Amy Pearson (MNHP) for making the map. 


\section{TABLe OF Contents}

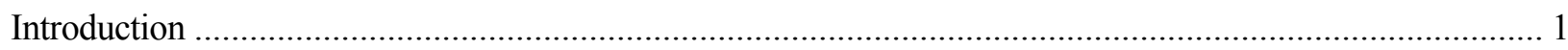

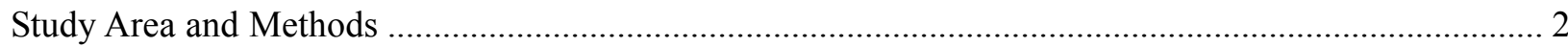

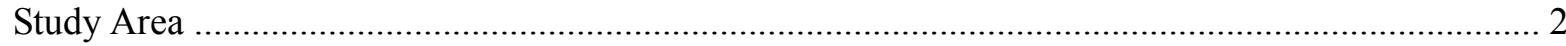

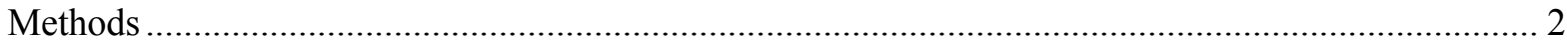

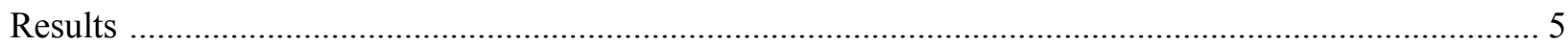

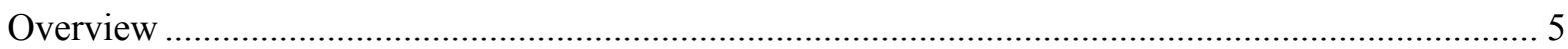

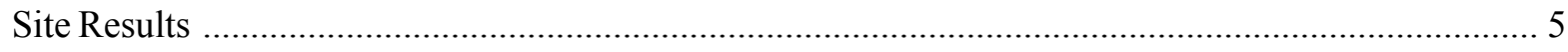

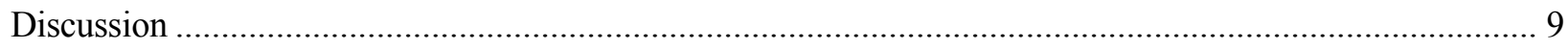

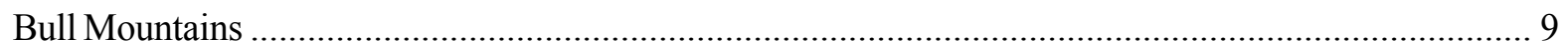

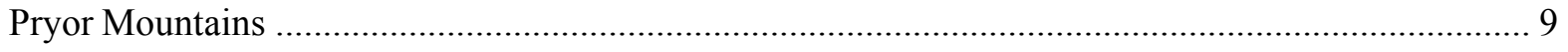

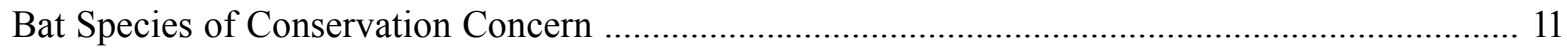

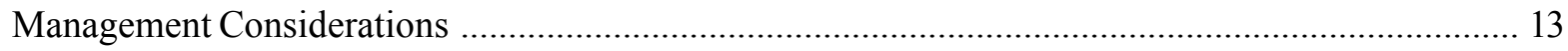

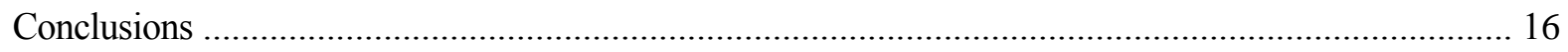

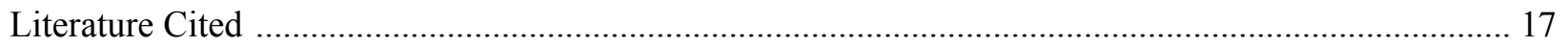

Appendix A Global/State Rank Definitions

Appendix B Bats Captured or Recovered During 2001-2003 Surveys in the Pryor Mountains, Carbon County, Montana

\section{LiST OF Figures}

Figure 1. Survey area of BLM Billings Field Office lands in south-central Montana .............................................. 3

\section{LisT OF TABLES}

Table 1. Sites in the Pryor Mountains and Bull Mountains sampled for bats during 2001-2003 ...................... 4

Table 2. Sex ratios of all bats captured or found in the Pryor Mountains during the 2001-2003 surveys ............. 5

Table 3. Documented elevational distributions of bats in the Pryor Mountains ....................................... 10

Table 4. Pallid Bat, Townsend's Big-eared Bat, and Spotted Bat reported locations in the Pryor Mountains ..... 12 


\section{INTRODUCTION}

There has been growing concern in recent decades regarding the status of bats throughout North America due to recognition that a variety of habitats traditionally used by bats for roosting and foraging have been subjected to widespread disturbance, alteration, reduced availability, or complete removal (Fenton 1997, Pierson 1998), and because of a general lack of basic natural history information (Hayes 2003). Six species or subspecies of bats in the continental United States currently are classified as endangered under the United States Endangered Species Act of 1973 (O'Shea et al. 2003), although none of these bats occur in Montana.

Conservation efforts for bats in Montana are often hampered by a lack of data on their habitat requirements. For example, the little data available from Montana on foraging and diet of bats, which help determine the suitability of roost sites, have been obtained largely at water sources (Jones et al. 1973), with no knowledge of where the foraging bats are roosting. Conversely, studies of bat roosts in Montana (e.g., Worthington 1991a, 1991b, Hendricks et al. 2000) lack information on where and how far the roost members go to feed and drink. In addition, patterns of roost selection and fidelity (e.g., Sherwin et al. 2003) have not been studied in Montana. This means there is considerable uncertainty about how to offer bats the most effective protection, be it directed to the bats themselves, their foraging areas, or their roosts (Fenton 1997). Nevertheless, suitable summer and winter roosts may limit local and regional distribution and abundance of many temperate-zone bats (Humphrey 1975, Dobkin et al. 1995), especially cave- and crevice-dwelling taxa. Thus conservation and protection of roosts are important long-term management strategies for many North American bat species (Sheffield et al. 1992).

Most bat species use a variety of localized habitats for roosting, be they natural sites (e.g., caves, trees, rock crevices) or man-made sites (e.g., buildings, mines, bridges). Sites may be used only during specific seasons of the year, and then for different purposes (e.g., a cave may be used only during winter for hibernation, while a building may be used only during summer as a maternity roost). Recent research on bat roosts in Montana has followed the general national pattern of inventorying and monitoring roosts in caves and abandoned mines (e.g., Worthington 1991a, 1991b, Hendricks et al. 2000, Hendricks and Kampwerth 2001), and this remains an important activity for a state bat conservation plan.

South-central Montana has the most diverse bat fauna of any region of the state (Foresman 2001). At least three species of conservation concern are found here (Carlson 2003), two of which, Pallid Bat (Antrozous pallidus) and Spotted Bat (Euderma maculatum), are at the northern limit of their global distribution in the Rocky Mountains (Adams 2003), and have not yet been documented in other regions of the state. The diversity of the bat fauna and the conservation significance of its membership make this region especially important for the success of a statewide bat conservation plan. 


\section{Study Area ANd Methods}

\section{Study Area}

Our bat survey was focused on the Pryor

Mountains, Carbon County, south-central Montana, but also included a preliminary survey in the Bull Mountains, Musselshell County, near Roundup (Figure 1). This region of the BLM Billings Field Office was chosen for study because 1) it supports probably the greatest diversity of bat species (10 confirmed) in Montana (Foresman 2001), including three species on the joint Montana Natural Heritage Program/Montana Fish, Wildlife and Parks Animal Species of Concern list (Carlson 2003), and 2) prior (Swenson and Bent 1977, Shryer and Flath 1980, Anderson et al. 1987, Worthington 1991a, 1991b, Hendricks and Carlson 2001) concurrent (with Montana Department of Transportation), and on-going studies (with the BLM) in the region help place our survey results in a larger landscape context, and 3) no surveys had been conducted during the last decade to determine the continued presence of the three bat species of conservation concern.

The Pryor Mountains of Carbon County lie near the Wyoming state line to the west of the Big Horn River and are separated from the Big Horn Mountains by the impressive gorge of Big Horn Canyon. The Pryor Mountains are a series of asymmetric anticlines forming four major uplifted mountain blocks (Campbell 1978). Nearly all of the surface rock of the Pryor Mountains is uplifted Madison Group limestone, which harbors numerous solution caves in the upper portions of the Madison Canyon Formation. Base elevation on the southern slopes of Big Pryor Mountain is about $4600 \mathrm{ft}$. $(1402 \mathrm{~m})$, reaching $8786 \mathrm{ft} .(2678 \mathrm{~m})$ at the summit. The Bull Mountains of Musselshell and Yellowstone counties are a region of moderately uplifted and eroded sandstone bluffs and cliffs. Elevations range from a base of about $3200 \mathrm{ft}$. (975 $\mathrm{m})$ to $4700 \mathrm{ft}$. (1433 m).

Based on the U.S. Forest Service's National Hierarchical Framework of Ecological Units, the study area largely occurs in the Powder River Basin Section, with a portion of Carbon County in the Bighorn Basin Section (Nesser et al. 1997).
The area is characterized by a cold continental climate with warm to hot, dry summers and cold, dry winters. Mean annual precipitation ranges from 25.5-35.5 cm (10-14 inches) in the Powder River Basin Section, with 30 percent falling as snow. In the Bighorn Basin Section, mean annual precipitation is $12.5-30.5 \mathrm{~cm}$ (5-12 inches).

Uplifted areas on southern slopes of the Pryor Mountains, in the Bighorn Basin Section, support arid woodlands of Utah juniper (Juniperus osteosperma) and limber pine (Pinus flexilus) that grade into Rocky Mountain juniper (Juniperus scopulorum), lodgepole pine (Pinus contorta), and Douglas-fir (Pseudotsuga menziesii) at increasingly higher elevations. The Bull Mountains, in the Powder River Basin Section, are an expanse of uplands, largely of sandstone and shale, supporting grassland and shrubland in a matrix of ponderosa pine (Pinus ponderosa) woodland. Flood plain cottonwood (Populus deltoides) gallery forest and other riparian woodlands are present along the Yellowstone River and tributaries. Land use in both sections is largely livestock grazing and some dryland farming, with strips of irrigated farmland along river and stream bottoms. However, there has been localized mining activity in both areas: uranium, bentonite, and limestone in the Pryors, and coal in the Bulls. One large urban center, Billings, is present along the Yellowstone River between the Bull Mountains and Pryor Mountains.

\section{Methods}

We sampled bats during summer of 2001-2003 at 14 sites (three caves, six mine workings, two springs/ponds, and three woodland areas), and examined four additional mines and two caves during daylight hours for evidence of use by bats (Table 1). Bats were captured using 50-denier mist nets of various lengths, usually 8-18 ft. (2.5-6.0 m) at mine portals and cave mouths, with sizes up to $40 \mathrm{ft}$. (12 m) also deployed at spring/ponds and woodland sites. We used an electronic bat detector, either Anabat II (Titley Electronics, Ballina, Australia) or Pettersson D240x (Pettersson Elektronik AB, Uppsala, Sweden), to aid in 
Figure 1. Survey Locations for Bats in South Central Montana, 2001-2003 (Location Numbers Correspond to Table 1).

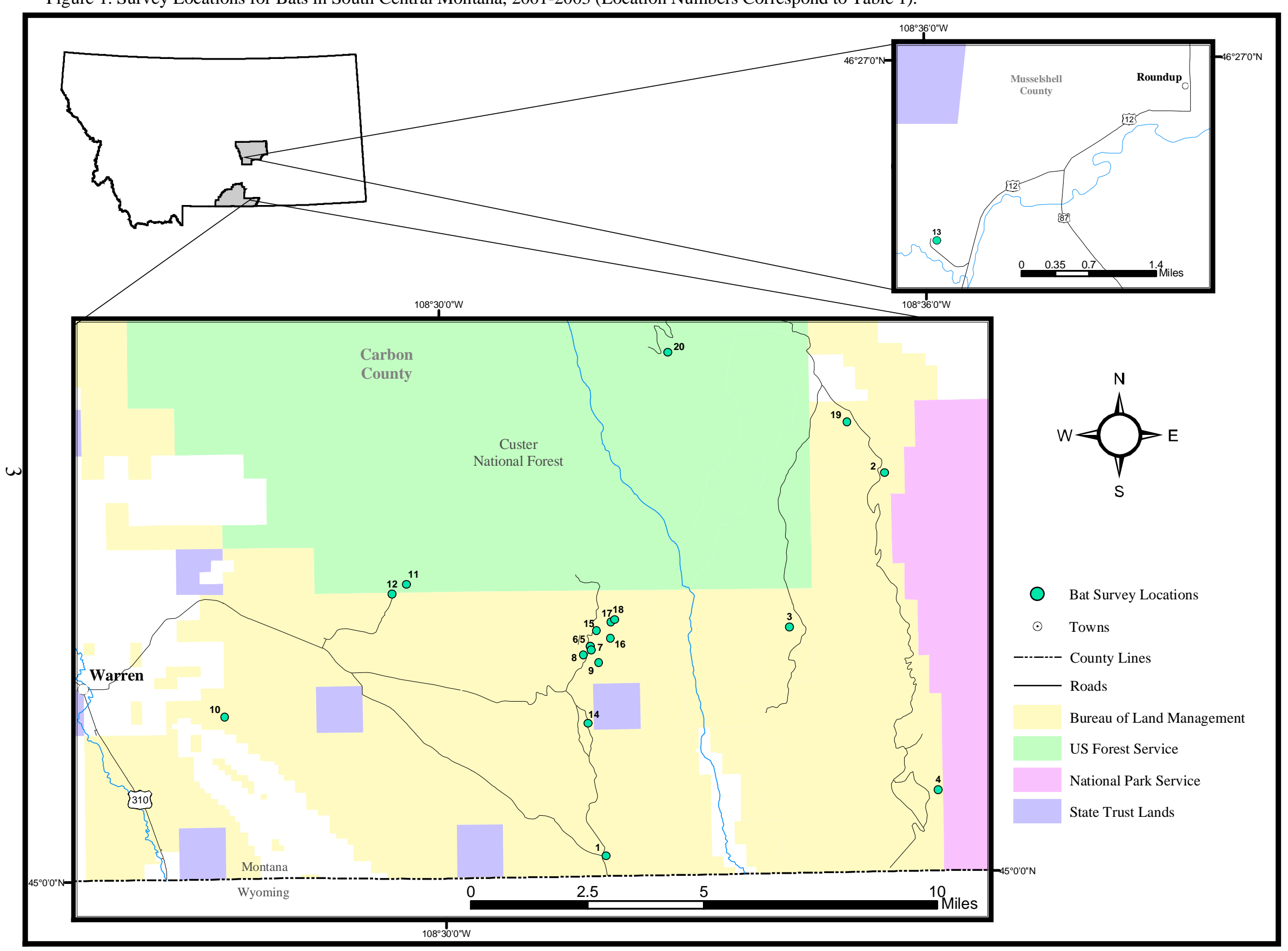


Table 1. Sites in the Pryor Mountains and Bull Mountains sampled for bats during 2001-2003. Numbers correspond to locations shown in Figure 1 and capture sites listed in Appendix 1.

\begin{tabular}{||l|l|c|c|l||}
\hline \multicolumn{1}{|c|}{ Site name } & \multicolumn{1}{|c|}{ Legal description } & County & $\begin{array}{c}\text { Elev. } \\
\text { (ft) }\end{array}$ & \multicolumn{1}{|c|}{$\begin{array}{c}\text { Sample } \\
\text { method }\end{array}$} \\
\hline \hline 1: Gyp Spring & T92 R27E, Sec 33NWSW & Carbon & 4600 & net \\
\hline 2: Mystery Cave & T8S R28E, Sec. 21SENW & Carbon & 7800 & net \\
\hline 3: Royce Cave & T9S R28E, Sec. 6SWSW & Carbon & 6160 & net, inspect \\
\hline 4: Four Eared Bat Cave & T9S R28E, Sec. 27SWNW & Carbon & 5040 & net, inspect \\
\hline $\begin{array}{l}\text { 5: Dandy Mine Upper West } \\
\text { (adit \#4) }\end{array}$ & T9S R27E, Sec. 8NENE & Carbon & 6150 & net, inspect \\
\hline $\begin{array}{l}\text { 6: Dandy Mine Upper West } \\
\text { (adit \#5) }\end{array}$ & T9S R27E, Sec. 8NENE & Carbon & 6150 & net, inspect \\
\hline $\begin{array}{l}\text { 7: Dandy Mine Lower West } \\
\text { (adit \#6) }\end{array}$ & T9S R27E, Sec. 8NENE & Carbon & 6120 & net, inspect \\
\hline 8: Marie Mine & T9S R27E, Sec. 8SESE & Carbon & 6000 & net, inspect \\
\hline 9: Robert's Incline Mine & T9S R27E, Sec. 9NWSW & Carbon & 5865 & net \\
\hline $\begin{array}{l}\text { 10: Bear Canyon Road Stock } \\
\text { Pond }\end{array}$ & T9S R26E, Sec. 18NWSW & Carbon & 4745 & net \\
\hline 11: Bear Canyon & T9S R26E, Sec. 34NESE & Carbon & 5500 & inspect* \\
\hline $\begin{array}{l}\text { 12: Bear Canyon BLM } \\
\text { Campground }\end{array}$ & T9S R26E, Sec. 3NWNE & Carbon & 5400 & net \\
\hline 13: Lowery Ranch HQ & T8N R25E, Sec. 28SENE & Musselshell & 3305 & net, inspect \\
\hline $\begin{array}{l}\text { 14: Swamp Frog Mine } \\
\text { (central site \#1) }\end{array}$ & T9S R27E, Sec. 17NESE & Carbon & 5400 & net, inspect \\
\hline 15: CM \& M Mine West & T9S R27E, Sec.4SWSW & Carbon & 6500 & inspect \\
\hline 16: CM \& M Mine East & T9S R27E, Sec.4SESW & Carbon & 6470 & inspect \\
\hline 17: Lisbon Mine West & T9S R27E, Sec.4NESW & Carbon & 6800 & inspect \\
\hline 18: Lisbon Mine East & T9S R27E, Sec. 4NESW & Carbon & 6800 & inspect \\
\hline 19: Salt Lick Cave & T8S R28E, Sec. 17SWNE & Carbon & 8280 & inspect \\
\hline 20: Big Ice Cave & T8S R27E, Sec. 3SWSE & Carbon & 7530 & inspect \\
\hline \hline
\end{tabular}

* Desiccated bats found during hike (Hendricks et al. 2003).

detecting the presence of bats in the area while we operated mist nets; only those sites netted were also monitored with an electronic bat detector.

Typically, nets were deployed at dusk and operated for at least 3-4 hours (usually until midnight or later) when conditions were favorable (no more than light winds and no rain). Captured bats were identified with the aid of keys (van Zyll de Jong 1985, Nagorsen and Brigham 1993); individuals were sexed, aged, measured (forearm, with a dial caliper to the nearest $0.1 \mathrm{~mm}$; weight, with a Pesola spring scale to the nearest $0.1 \mathrm{~g}$ ), reproductive status noted, marked on the dorsal surface of the uropatagium with a felt-tip marker, and released. We also analyzed recorded bat vocalizations on-site in 2003 , and contrasted recorded vocalizations to reference calls and their written descriptions, through use of SonoBat 2 software (DNDesign, Jacksonville, Florida) loaded on a laptop computer.

We inspected accessible mines and caves when possible and deemed safe. For each mine, we documented the presence of open portals and noted portal dimensions, obstructions, and the presence of bats or bat spoor. Internal mine dimensions were measured with a cloth meter-tape, or estimated. Mine ambient temperature and relative humidity, when recorded, were measured with a sling psychrometer. Caves without gates were examined for the presence of bats or bat spoor during the day, but none at which we netted were given a thorough exploration.

Statistical analyses follow standard procedures (Sokal and Rohlf 1981), with statistical significance assumed at $\mathrm{P}<0.05$. 


\section{Results}

\section{Overview}

We captured or observed a total of 150 individual bats of eight species during 21 nights of netting: Pallid Bat, Antrozous pallidus (1 from one site); Townsend's Big-eared Bat, Corynorhinus townsendii (8 from four sites); Big Brown Bat, Eptesicus fuscus (13 from four sites); Hoary Bat, Lasiurus cinereus (1 from one site); Western Small-footed Myotis, Myotis ciliolabrum (32 from eight sites); Western Long-eared Myotis, Myotis evotis (80 from eight sites); Little Brown Myotis, Myotis lucifugus (6 from one site); and Longlegged Myotis, Myotis volans (9 from three sites).

For the total sample of bats we encountered from the Pryor Mountains, the majority were males ( 95 males, 49 females; $G=7.576$, $\mathrm{df}=1, P<0.01$ ), but the Western Long-eared Myotis was a notable exception, with the largest sample size for any species (Table 2) and a sex ratio near unity. Too few bats were captured in the Bull Mountains (two males of two species) for a comparable analysis.

We detected three bat Species of Concern during our surveys. A Pallid Bat (G5, S2; See Appendix A for Rank definitions) was captured at one site along the base of the Pryor Mountains where the species was first documented in Montana in 1978, Townsend's Big-eared Bats (G4, S2) were captured at two caves in the Pryor Mountains where the species was reported in 1990, at a new canyon site in the Pryor Mountains, and at a new bluff site in the Bull Mountains. Although we failed to capture any Spotted Bats (G4G5, S2) during our survey, we heard or recorded their vocalizations at nine netting sites, including one location in the Bull Mountains. We detected all of the species listed in Table 2, as well as Spotted Bat, in the Pryor Mountains, and three species (Spotted Bat, Townsend's Big-eared Bat, Western Long-eared Myotis) in the Bull Mountains. Inspection and netting results for each of the 20 sample sites listed in Table 1 are given below; numbers correspond to those given in Figure 1 and Appendix B. Bats were identified only at the first 14 sites; no bats were observed at the remaining sites, although we did note evidence of their presence at some locations.

\section{Site Results}

1) Gyp Spring: We netted along the outflow in the stream channel just below the spring and along the bluff above the channel on 14 July 2001, 8 August 2002, and 9 September 2003. We captured seven individual bats of six species: Pallid Bat (1), Big Brown Bat (1), Hoary Bat (1), Western Small-footed Myotis (2), Western Long-eared Myotis (1), and Long-legged Myotis (1). The Pallid Bat was a lactating female; all other individuals were males or

Table 2. Sex ratios of all bats captured or found in the Pryor Mountains during the 2001-2003 surveys. Unknowns were not used in the statistical tests.

\begin{tabular}{|l|c|c|c|c|c|c|}
\hline \multicolumn{1}{|c|}{ Species $^{1}$} & Total & Males & Females & Unknown & G-test & $\boldsymbol{P}$ \\
\hline \hline ANPA & 1 & --- & 1 & --- & --- & --- \\
\hline COTO & 7 & 2 & 5 & --- & 1.327 & $>0.1$ \\
\hline EPFU & 13 & 10 & 3 & --- & 3.976 & $<0.05$ \\
\hline LACI & 1 & 1 & --- & --- & --- & --- \\
\hline MYCI & 32 & 29 & 2 & 1 & 28.134 & $<0.001$ \\
\hline MYEV & 79 & 39 & 37 & 3 & 0.052 & $>0.5$ \\
\hline MYLU & 6 & 6 & --- & --- & --- & --- \\
\hline MYVO & 9 & 8 & 1 & --- & 6.198 & $<0.01$ \\
\hline
\end{tabular}

${ }^{1}$ ANPA (Pallid Bat: Antrozous pallidus), COTO (Townsend's Big-eared Bat: Corynorhinus townsendii), EPFU (Big Brown Bat: Eptesicus fuscus), LACI (Hoary Bat: Lasiurus cinereus), MYCI (Western Smallfooted Myotis: Myotis ciliolabrum), MYEV (Western Long-eared Myotis: Myotis evotis), MYLU (Little Brown Myotis: Myotis lucifugus), MYVO (Long-legged Myotis: Myotis volans). 
of unknown sex (Appendix B). We also heard Spotted Bat at this site in 2002 and 2003, between 20:50-24:00. Recorded calls on 9 September 2003 were tentatively identified as Western Small-footed Myotis, Western Long-eared Myotis, Little Brown Myotis, and Long-legged Myotis.

2) Mystery Cave: We netted at this cave on 15 July 2001. We captured 18 individual bats of four Myotis species: Western Small-footed Myotis (1), Western Longeared Myotis (10), Little Brown Myotis (6), Long-legged Myotis (1). All individuals were male, with the exception of a nonlactating female Western Small-footed Myotis (Appendix B). We also heard Spotted Bat between 22:28-22:38. The cave is gated and we did not enter it.

3) Royce Cave: We netted at this cave on 16 July 2001 and 6 August 2002. We captured 23 individual bats of three species: Townsend's Big-eared Bat (1), Western Small-footed Myotis (2), Western Long-eared Myotis (20). Eleven of the 20 Western Long-eared Myotis were female, three of which were lactating on 6 August 2002 (Appendix B). One of the lactating females carried a numbered blue wing band, and had been marked as an adult at this same cave on 26 June 1990 (D. Worthington personal communication). The solitary Townsend's Big-eared Bat was a non-reproductive female; all other bats were males. We also heard Spotted Bat pass overhead near the cave at 00:15 on 17 July 2001. We explored this cave during the day on both visits, but found no bats occupying it; our explorations were not complete, however.

4) Four Eared Bat Cave: We netted at this cave on 7 August 2002. We captured eight individual bats of two species: Townsend's Big-eared Bat (3), Western Small-footed Myotis (5). All of the Townsend's Bigeared Bats were non-reproductive females; all Western Small-footed Myotis were scrotal males (Appendix B). Prior to netting we fully explored this cave and found a single female Townsend's Bigeared Bat, with ears tucked under her wings, roosting from the ceiling in the first declining section about $20 \mathrm{~m}$ from the mouth. Ambient temperature at the bat was $56^{\circ} \mathrm{F}$ at 18:00. We also heard Spotted Bat pass overhead between 21:22-21:38.

5) Dandy Mine Upper West (adit \#4): We netted at this mine adit on 25 July 2001, 4 and 5 September 2001, and 9 August 2002. We captured 74 individual bats of four species: Big Brown Bat (8), Western Small-footed Myotis (18), Western Longeared Myotis (41), Long-legged Myotis (7). Three of the Western Long-eared Myotis on 25 July 2001, and 13 on 9 August 2002, were lactating females; a lactating female Long-legged Myotis was also captured on 9 August 2002 (Appendix B). A juvenile male Western Small-footed Myotis was captured on 25 July 2001. We also heard Spotted Bat pass overhead at 01:45 on 26 July 2001. Standing water was visible from the portal, and we witnessed bats entering the mine and getting drinks from this pool while we netted. We explored this mine during the day on 9 August 2002, but saw no roosting bats, although scattered droppings were present to the lowest level of the mine (the portal is on the upper-most level). Ambient temperature in the large "dome room" was $43^{\circ} \mathrm{F}$, with $94 \%$ relative humidity.

6) Dandy Mine Upper West (adit \#5): We netted at this mine adit on 25 July 2001. We captured three individual bats of one species, the Big Brown Bat (all males). On 9 August 2002 we found a dead Western Long-eared Myotis (sex undetermined) at the portal (Appendix B). We fully inspected this shallow mine, located about 20 m east of "Adit \#4", on 25 July 2001 and 9 August 2002, but found no roosting bats. We heard Spotted Bat at 01:45 on 26 July 2001 near this site, the 
same individual mentioned above at "Adit \#4."

7) Dandy Mine Lower West (adit \#6): We netted this mine adit on 27 July 2001. We captured a single male Western Smallfooted Myotis (Appendix B). We fully inspected this working on 25 and 28 July 2001, noted scattered bat droppings to the drift face, but found no roosting bats.

8) Marie Mine: We netted this mine adit on 24 July 2001. We captured two individual bats of two species: Big Brown Bat (1), Western Small-footed Myotis (1). Both individuals were non-scrotal males (Appendix B). We fully explored this mine on 25 July 2001, and found scattered bat droppings to the most remote workings, but saw no roosting bats.

9) Robert's Incline Mine: We netted this mine adit on 28 July 2001. We captured two male Western Small-footed Myotis (Appendix B). We also heard Spotted Bat pass overhead just upslope from this working at 00:20 on 29 July 2001. We did not inspect this mine because we determined a partially collapsed ceiling made entry unsafe.

10) Bear Canyon Stock Pond: We netted at this site on 27 and 28 August 2002. Strong winds prevented capture of the few bats present on 27 August. We captured four female Western Long-eared Myotis on 28 August, two of which were post-lactating (Appendix B). There is a well and stock tanks adjacent to this overflow pond. Both the tanks and pond can be dry when water is not being pumped from the well for livestock. Thus, this site is an ephemeral source of water and insects for bats.

11) Bear Canyon: We hiked the canyon onto Custer National Forest lands on 28 August 2002. During the hike we found two desiccated Western Long-eared Myotis tangled in the flower heads of burdock
(Arctium minus) lining the trail adjacent to a riparian woodland strip of narrowleaf cottonwood (Populus angustifolia) about 0.2 miles up-canyon from the BLM Campground (see Hendricks et al. 2003).

12) Bear Canyon BLM Campground: We netted at this site, under the narrowleaf cottonwoods in the canyon bottom and flanked by limestone scarps, on 10 and 11 September 2003. We captured two male and one female Townsend's Big-eared Bat (Appendix B); the female, captured on 10 September, was post-lactating. We also heard and recorded Spotted Bat passing overhead during 20:15-20:30 on 10 September. Other calls recorded during both nights of netting were tentatively identified as Big Brown Bat, Hoary Bat, Silver-haired Bat (Lasionycteris noctivagans), Western Small-footed Myotis, Western Long-eared Myotis, Little Brown Myotis, and Long-legged Myotis.

13) Lowery Ranch $H Q$ : We netted this site in the Bull Mountains, Musselshell County on 12 and 13 September 2003. Cold rainy weather and wind reduced netting success. We captured two male bats of two species: Townsend's Big-eared Bat (1), Western Long-eared Myotis (1). Both individuals were captured both nights. The Myotis was captured in a wooden barn while it hunted noctuid moths; it apparently roosted during the day in the barn. The Townsend's Big-eared Bat was captured near an abandoned powder house carved into the face of a sandstone cliff and blocked with a solid metal door, making the powder house much like a small pocket cave $(2.5 \mathrm{~m}$ in height, $5.0 \times 5.0 \mathrm{~m}$ in length and width); this same individual bat was found day-roosting on the ceiling of the powder house on 12 September. Respective forearm and weight measurements (not listed in Appendix B) were $44.0 \mathrm{~mm}$ and $10.5 \mathrm{~g}$ for the Townsend's Big-eared Bat, and $36.7 \mathrm{~mm}$ and $7.0 \mathrm{~g}$ for the Western Long-eared 
Myotis. We also heard Spotted Bat pass overhead near the powder house at 20:30 on 13 September. Other calls recorded on 13 September, and during a later visit on 19 and 20 September 2003, included those tentatively identified as Big Brown Bat, Hoary bat, Western Small-footed Myotis, Western Long-eared Myotis, Little Brown Myotis, and Long-legged Myotis.

14) Swamp Frog Mine (central site \#1): We netted this pair of shallow adits (ca. $3 \mathrm{~m}$ apart) on 17 July 2001. We failed to capture any of the 3-4 bats (Myotis size) that appeared at the portals. We fully explored both shallow workings during daylight and found scattered bat droppings in the longer adit, but saw no roosting bats. We heard Spotted Bat pass overhead near this site at 00:15 on 18 July 2001 .

15) $C M \& M$ Mine West: We did not net this mine working, but fully inspected it on 27 July 2001. We found scattered bat droppings throughout this shallow tunnel, but saw no roosting bats.

16) $C M$ \& M Mine East: We did not net this mine adit, but fully inspected it on 27 July 2001. We found a few scattered bat droppings near the drift face, but saw no roosting bats.

17) Lisbon Mine West: We did not net this mine adit, but visited the site on 25 and 26 July 2001. We found no sign of bat activity because the portal was gated and seemed to be actively worked; it appeared, nevertheless, that bats could pass through the gate (a grid of rebar with $20 \times 20 \mathrm{~cm}$ spacing).

18) Lisbon Mine East: We did not net this shallow mine adit, but fully inspected it on 25 and 26 July 2001 . We found no bat droppings or roosting bats.

19) Salt Lick Cave: We did not net this small high-elevation cave located near the ridge crest of East Pryor Mountain, but fully inspected it during daylight on 15 July 2001. We found evidence of recent human visitation, only one bat dropping, and no roosting bats.

20) Big Ice Cave: We did not net this cave, but fully inspected the upper room during daylight on 29 August 2002 (access to the lower room was blocked with ice). We found evidence of recent human visitation, but no bat droppings or roosting bats. 


\section{DisCUSSION}

\section{Bull Mountains}

Very little has been published regarding the bat fauna of the Bull Mountains in Musselshell County, and the list of documented species is incomplete. Only two species have been reported in the literature prior to our brief survey: Townsend's Bigeared Bat and Western Small-footed Myotis (Swenson 1970, Foresman 2001). To this list we added Spotted Bat and Western Long-eared Myotis in 2003. There are unpublished reports on bats associated with sites of proposed coal mine development (Meridian Bull Mountains Mine) 16 miles southeast of Roundup and east of U.S. 87. We were unable to review the reports prior to the development of this report, but we were told that Townsend's Big-eared Bat was captured and Spotted Bat heard (Tom Butts; personal communication).

We anticipate a thorough survey of the Bull Mountains will result in a list of bat species identical to that of the Pryor Mountains. In support of this contention, several species yet to be documented in Musselshell County have been captured to the south in Yellowstone County, which occupies a central position between the Bull Mountains and the Pryor Mountains. Near the southern base of the Bull Mountains, 15 miles north northeast of Shepherd, Swenson and Bent (1977) captured Hoary Bat and Long-legged Myotis, as well as Western Small-footed Myotis and Western Long-eared Myotis. Nine species of bats have been reported from Yellowstone County (Hoffmann et al. 1969, Swenson and Bent 1977, Foresman 2001), including the first record of Spotted Bat for Montana (Nicholson 1950). Pallid Bat is the only species known from the Pryor Mountains that remains unreported from either Yellowstone or Musselshell counties.

Documented roost sites in the Bull Mountains are almost nonexistent. Townsend's Big-eared Bat and Western Small-footed Myotis have been found hibernating in an abandoned underground coal mine (Swenson 1970). Since discovery, most abandoned mines in the Bull Mountains have been reclaimed, including a former hibernaculum; reclamation involved sealing the mines and making them inaccessible to bats. The only other reported roosts in the Bull Mountains of which we are aware are the two we found during our survey in 2003, just southwest of Roundup near Pole Creek: a male Western Long-eared Myotis day-roosting in a barn, and a male Townsend's Big-eared Bat day-roosting in an artificial sandstone "cave" (a powder house carved out of a sandstone cliff). A maternity colony of a yet-to-be-determined species of Myotis occupies the farm house at this location (Bette Lowery; personal communication); we sampled the site in September, well after the colony had dispersed. During summer, many species probably use tree cavities (especially in the numerous firekilled ponderosa pine snags) and crevices in the sandstone cliffs as roost habitat, but the magnitude of use of these habitat features needs study; winter roosts are essentially unknown, especially following destruction in the 1980's of the only known hibernaculum.

\section{Pryor Mountains}

The Pryor Mountains have received as much study of their bat fauna as any other landscape in

Montana. This is due to 1) the presence of a large and concentrated collection of limestone caves on public lands that provide bats with a diversity of roosting conditions (Campbell 1978), and 2) interest in recent decades in the status of three bat species considered rare or of conservation concern in Montana.

Ten species of bats are known to occur in the Pryor Mountains and adjacent Bighorn Canyon National Recreation Area (Shryer and Flath 1980, Anderson et al. 1987, Worthington 1991a, 1991b, Hendricks and Carlson 2001). A California Myotis (Myotis californicus) specimen, reported from Bighorn Canyon by Anderson et al. (1987), has since been identified as a Western Small-footed Myotis (Worthington 1991b). Three of the ten confirmed species (Pallid Bat, Townsend's Bigeared Bat, Spotted Bat) are state species of conservation concern (Carlson 2003). During our 2001-2003 survey we documented the continued presence of all species but the Silver-haired Bat 
(Lasionycteris noctivagans), which we also tentatively identified at one site, based only on recorded vocalizations.

\section{Sex Ratios and Evidence of Reproduction}

Males were captured more frequently than females during our sampling, a pattern that tended to apply to all species (Table 2); exceptions were Townsend's Big-eared Bat, with slightly more females, and Western Long-eared Myotis, with essentially a 50:50 sex ratio. A sex ratio favoring males was also noted for most species by Worthington (1991a, 1991b), and appears to be a pattern general to other areas of Montana, such as the Little Rocky Mountains of Phillips and Blaine counties (Hendricks et al. 2000).

Reasons for the disparity in sex ratios are unclear, but probably are related to some degree of habitat segregation by the sexes, which could be confounded by pooling uneven samples across all sites and elevations. Nevertheless, females tend to be more abundant at lower elevations, where roost environments are more favorable for raising young (Cryan et al. 2000). In the Pryor Mountains, male Western Long-eared Myotis were more abundant than females in pooled samples at Mystery Cave (7800 ft.) and Little Ice Cave (8180 ft.), but females were equally or more abundant than males in pooled samples from mid and lower elevations, such as Royce Cave (6160 ft.) or the Dandy Mine Upper West (\#4) Adit (6150 ft.) (Worthington 1991a, 1991b; this study).
During our survey of the Pryor Mountains, we documented evidence of breeding by female bats (lactation, juveniles) of five species (Appendix B): Pallid Bat, Townsend's Big-eared Bat, Western Small-footed Myotis, Western Long-eared Myotis, Long-legged Myotis. For all species for which we captured males, at least some were in reproductive condition (testes in scrotal position), with the exception of the lone male Hoary Bat. Female Hoary Bats with offspring have been found in adjacent counties of south-central Montana (e.g., Hendricks et al. submitted), and they probably raise offspring at selected localities in the Pryor Mountains as well. Worthington (1991a, 1991b) does not clearly indicate if breeding was documented for all species he captured, but he indicated that Spotted Bat breeds in the area, by capturing a lactating female and a volant juvenile.

\section{Elevational Distribution}

The majority of bat species found in the Pryor Mountains occur over a relatively broad elevation range, even up to the crest of the mountains at $8000 \mathrm{ft}$. elevation or more (Table 3). However, there is a group of three species (Pallid Bat, Hoary Bat, Silver-haired Bat) that has been reported only below $6000 \mathrm{ft}$.; all of these are absent during winter. Of the remaining seven species, only the Spotted Bat is not likely to hibernate in the region, and it, too, is probably most common in summer in the lower and drier parts of the area. The relative distribution of different bat species along an elevation gradient in the Pryor Mountains is similar

Table 3. Documented elevational distributions of bats in the Pryor Mountains, based on all contemporary records (Dennis Flath personal communication; Worthington 1991a, 1991b; Madson and Hanson 1992; Hendricks and Carlson 2001; this study).

\begin{tabular}{|l|c|c||}
\hline \multicolumn{1}{|c|}{ Species } & $\begin{array}{c}\text { Lower elevation } \\
\text { (ft) }\end{array}$ & $\begin{array}{c}\text { Upper elevation } \\
\text { (ft) }\end{array}$ \\
\hline \hline Pallid Bat (Antrozous pallidus) & 3690 & 4600 \\
\hline Townsend's Big-eared Bat (Corynorhinus townsendii) & 3690 & 7800 \\
\hline Big Brown Bat (Eptesicus fuscus) & 3690 & 7870 \\
\hline Spotted Bat (Euderma maculatum) & 3690 & 7800 \\
\hline Hoary Bat (Lasiurus cinereus) & 3690 & 5500 \\
\hline Silver-haired Bat (Lasionycteris noctivagans) & 3690 & 5500 \\
\hline Western Small-footed Myotis (Myotis ciliolabrum) & 3690 & 8180 \\
\hline Western Long-eared Myotis (Myotis evotis) & 4265 & 8180 \\
\hline Little Brown Myotis (Myotis lucifugus) & 3690 & 8180 \\
\hline Long-legged Myotis (Myotis volans) & 4265 & 8180 \\
\hline
\end{tabular}


in pattern to that reported elsewhere in the western United States for the same suite of species (e.g., Szewczak et al. 1998).

\section{Roosts}

Few roosting sites, other than caves and mines, have been documented in the Pryor Mountains. Two caves, Little Ice Cave and Mystery Cave, support substantial numbers of hibernating Myotis bats (Madson and Hanson 1992); hibernating bats have been reported in four other caves (Four Eared Bat, Syke's, Frogg's Fault, Big Ice) and two mines (Dandy Upper West adit \#4, Lisbon West). Bats were identified as Townsend's Big-eared Bat (four caves, two mines), Big Brown Bat (one cave) Western Long-eared Myotis (one cave), and unidentified Myotis (five caves, two mines).

During our surveys we found only one summer day-roosting bat, a female Townsend's Big-eared Bat in Four Eared Bat Cave on 7 August 2002. Worthington (1991a) reported a single male Townsend's Big-eared Bat day-roosting in an unspecified shallow $(100 \mathrm{~m})$ mine adit, probably in the Dandy Mine area. Worthington and Ross (1990) reported a single day-roosting Little Brown Myotis in Mystery Cave on 14 and 23 August 1989, and three Little Brown Myotis in Little Ice Cave on 23 August 1989; they suggested that additional roosting individuals could have been concealed in cracks and were possibly overlooked. Worthington and Ross (1990) also reported finding three Longlegged Myotis with young on 17 July 1989 in the rafters of an abandoned building at Hillsboro, in Bighorn Canyon National Recreation Area. Big Brown Bat remains have been recovered from strata dating $>6000$ years old in False Cougar Cave on East Pryor Mountain (Bonnichsen et al. 1986); season of occupancy could not be determined but the cave is shallow and at $8465 \mathrm{ft}$. $(2580 \mathrm{~m})$ elevation, indicating it was probably used as a summer day-roost.

In summary, both summer and winter occupancy by bats has been reported at two caves and one mine (possibly two), with hibernating bats documented at four additional caves and one mine. Summer roosts have been reported for one additional cave (remains recovered from a second cave probably used as a day roost), one additional mine, and one abandoned building.

\section{Roost Fidelity}

Several bats observed in Mystery Cave during February and March 1992 by Madson and Hanson (1992) were banded during the summers of 1989 and 1990 by Worthington (1991a, 1991b), indicating that some Myotis are resident year round in the Pryor Mountains, although no marked individuals were identified to species. Worthington (1991a, 1991b) noted that there appeared to be little movement by bats between caves (potential roosts) during summer. Of 1079 marked individuals, only one was captured at a site other than where it was marked; a male Western Long-eared Myotis was recovered at Royce Cave, about 2000 feet lower in elevation and 4.5 miles south of Little Ice Cave, where it had been banded. On 16 July 2001 we captured a lactating female Western Long-eared Myotis at Royce Cave banded as an adult at the same cave on 26 June 1990 (Dave Worthington personal communication), making her at least 12 years old and still visiting the same cave during summer.

In summary, many individual bats appear to concentrate their activity to a few traditional sites during a single summer or multiple summers and tend not move between roosts, such as Mystery Cave and Little Ice Cave, even when the roosts are as close as 1 mile $(3 \mathrm{~km})$ apart (Worthington 1991b). Use of summer sites by individual bats could last for several years to more than a decade. Based on the appearance of banded bats at caves where they probably were marked two or three years previously, fidelity to hibernacula appears to be similar to summer roosts, but needs more study.

\section{Bat Species of Conservation Concern}

Pallid Bat (Antrozous pallidus) (G5, S1)

Pallid Bat has been captured at relatively few locations in the Pryor Mountains, and only during summer (Table 4). This species was first documented in Montana at Gyp Spring in 1978 (Shryer and Flath 1980), and again at this site in 1989, 1990 and 2002 (Worthington and Ross 1990, Worthington 1991b, this study); captured individuals 
in 1989, 1990 and 2002 included lactating females and juveniles. Pallid Bat has also been captured in Bighorn Canyon National Recreation Area at Layout Creek Ranger Station, Montana and Horseshoe Bend Campground, just into Wyoming (Worthington 1991a, 1991b); all of these individuals were males. All locations are in arid low-elevation habitats at water sources. Although not yet documented in the Bull Mountains, the Pallid Bat probably will be found there with more intensive survey effort, as the habitat is certainly suitable for their roosting and foraging requirements. Roost sites for Pallid Bat in the Pryor Mountains (and Montana) have not been documented, but could include rock crevices and abandoned buildings, as well as caves and mines (Adams 2003).

\section{Townsend's Big-eared Bat (Corynorhinus townsendii) (G4, S2S3)}

Townsend's Big-eared Bat has been captured or observed at eight caves and mines in the Pryor Mountains, and also netted while foraging in Bear Canyon (Table 4); a male was found roosting during summer in an abandoned building near Horseshoe Bend Campground, just into Wyoming (Worthington 1991a). Curiously, none have yet been captured at water sources. At least part of the population in the Pryor Mountains is likely resident year-round; individuals have been found at caves and mines during summer and winter (Worthington and Ross 1990, Worthington 1991b, Madson and Hanson 1992). One of the individuals captured by Worthington (1991b) was a juvenile; of the seven individuals we netted during 2001-2003, a female from Bear Canyon was post-lactating (Appendix B). The Pryor Mountains population is found over a wide range of elevations (Tables 3 and 4) and habitats (from arid lowlands to mesic conifer forest), but appears to be relatively small; the largest number of individuals reported at any location has been 15, in hibernation at Four Eared Bat Cave (Madson and Hanson 1992).

Hibernating Townsend's Big-eared Bats in the Pryor Mountains have been found at temperatures between $-0.5^{\circ}$ and $7.0^{\circ} \mathrm{C}$ (Madson and Hanson 1992, Hendricks and Kampwerth 2001); ambient temperature was $13.5^{\circ} \mathrm{C}$ near the day-roosting female we found in August 2002 at Four Eared Bat Cave. In the Bull Mountains there are two records of Townsend's Big-eared Bat: a March hibernaculum in an abandoned coal mine (Swenson 1970, Swenson and Bent 1977), and a single

Table 4. Locations where Pallid Bat, Townsend's Big-eared Bat, and Spotted Bat have been reported in the Pryor Mountains; all sites are in Montana unless indicated otherwise. Sources are given in brackets following site names, and listed at the bottom of the table. Codes are $\mathrm{S}, \mathrm{s}=$ summer, $\mathrm{W}, \mathrm{w}=$ winter; capitalized letters are for capture or winter sight records, lower case letters for vocalization records only.

\begin{tabular}{|l|c|c|c|c|}
\hline \multicolumn{1}{|c|}{ Site } & $\begin{array}{c}\text { Elevation } \\
\text { (ft) }\end{array}$ & Pallid Bat & $\begin{array}{c}\text { Townsend's } \\
\text { Big-eared Bat }\end{array}$ & $\begin{array}{c}\text { Spotted } \\
\text { Bat }\end{array}$ \\
\hline Horseshoe Bend (Wyoming) [3-4] & 3690 & $\mathrm{~S}$ & $\mathrm{~S}$ & $\mathrm{~s}$ \\
\hline Layout Creek [3-4] & 4265 & $\mathrm{~S}$ & & $\mathrm{~S}$ \\
\hline Gyp Spring [1-4, 7] & 4600 & $\mathrm{~S}$ & $\mathrm{~s}$ \\
\hline Four Eared Bat Cave [3-5,7] & 5040 & & $\mathrm{~S}, \mathrm{~W}$ & $\mathrm{~s}$ \\
\hline Bear Canyon Campground [7] & 5400 & & $\mathrm{~S}$ & $\mathrm{~s}$ \\
\hline Swamp Frog Mine [6-7] & 5400 & & $\mathrm{~S}$ & $\mathrm{~s}$ \\
\hline Robert's Incline Mine [3?, 6-7] & 5865 & & $\mathrm{~W}$ & \\
\hline Frogg's Fault Cave [5] & 6020 & & $\mathrm{~W}$ & $\mathrm{~s}$ \\
\hline Dandy Mine Upper West \#4 Adit [5-7] & 6150 & & $\mathrm{~S}$ & $\mathrm{~s}$ \\
\hline Dandy Mine Upper West \#5 Adit [6-7] & 6150 & & $\mathrm{~S}$ \\
\hline Royce Cave [3-4, 7] & 6160 & & $\mathrm{~W}$ & \\
\hline Lisbon Mine West [5] & 6800 & & $\mathrm{~W}, \mathrm{~W}$ & $\mathrm{~s}$ \\
\hline Big Ice Cave [5] & 7530 & & & \\
\hline Mystery Cave [3-5, 7] & 7820 & & & \\
\hline
\end{tabular}

Sources: (1) Shryer and Flath 1980, (2) Worthington and Ross 1990, (3) Worthington 1991a, (4)

Worthington 1991b, (5) Madson and Hanson 1992, (6) Hendricks and Carlson 2001, (7) this report. 
September male using a powder house for a dayroost (Appendix B). With additional surveys we anticipate Townsend's Big-eared Bat will be found at several other locations, but probably only in small numbers.

\section{Spotted Bat (Euderma maculatum) (G4, S1)}

Spotted Bat continues to be reported from the Pryor Mountains following the first documentation by Worthington (1991a, 1991b); all Montana records are from summer. A specimen (since lost?) found dead in 1981 near the Yellowtail Dam Visitor Center at the northern terminus of the Big Horn Mountains (MNHP databases) indicated their likely presence in the Pryor Mountains, as did the first Montana record in 1949 from Billings (Nicholson 1950). However, the two individuals netted by Worthington at the Layout Creek Ranger Station pond in Bighorn Canyon National Recreation Area in July 1990 (a lactating female and a juvenile female) remain the only Spotted Bats captured in the Pryor Mountains. A post-lactating female was captured on 27 August 1990 just across the border in Wyoming, east of Bighorn Canyon (Priday and Luce 1999). Detecting the presence of Spotted Bats is enhanced by the distinctive vocalizations that are audible to the unaided human ear (Adams 2003); the majority of records from the last 15 years in the Pryor Mountains are based on these alone, or a quick glance of a bat passing overhead associated with the calls. Spotted Bat has been reported across a wide range of elevations (Tables 3 and 4), but most encounters have occurred in arid juniper/sagebrush habitats at elevations below $6200 \mathrm{ft}$. (1890 m). In the Bull Mountains, Spotted Bat has been heard at one location (this report), but probably is found throughout the region at low numbers; additional surveys for this species in the Bull Mountains are desirable. Roost sites in Montana remain unreported, although Spotted Bats probably use crevices and small caves in the numerous high limestone and sandstone cliffs that are a prevalent part of the landscape (Adams 2003). Montana records from cave and mine sites are for Spotted Bats passing nearby, not visiting the caves or mines.
Fringed Myotis (Myotis thysanodes) (G4G5, S3)

Fringed Myotis has been reported only recently (2004) from the Pryor Mountains, at Bear Canyon Campground (Adam Messer personal communication), and needs verification. If valid, this constitutes the eleventh bat species confirmed for the Pryor Mountains. Fringed Myotis has been documented at a cave roost along the western flanks of the Bighorn Mountains nearby in Wyoming (Priday and Luce 1997). Nothing is known about the roosting habits of this species in Montana, but it could utilize caves, mines, and abandoned buildings (Adams 2003). Fringed Myotis has not yet been reported in the Bull Mountains.

\section{Management Considerations}

The development of a comprehensive conservation plan for bats in the Pryor Mountains should be promoted as a priority, but relatively low-cost, Bureau of Land Management activity, one that will be most effective and successful if done in coordination with the Custer National Forest, Bighorn Canyon National Recreation Area, and the Bureau of Indian Affairs and Crow Tribe; land-use activities on lands under stewardship of particular agencies and groups could affect the success of bat management activities on other parts of the Pryor Mountains landscape.

Most of the information we have on bats in the Pryor Mountains and Bull Mountains comes from sites that concentrate bat activity, such as caves, mines, and water sources. These landscape features provide important roosting and foraging benefits to bats, and continue to be places where bat activity is most easily inventoried and monitored (Pierson 1998, O'Shea et al. 2003), as well as where the negative impacts of human disturbance may be most severe. Maternity colonies and hibernacula are very vulnerable, and sensitive to disturbance. Thus, management for bats, particularly in the Pryor Mountains, should include protection of caves, mines, and water sources as an important component of a conservation plan. Management guidelines in the conservation assessment and strategy for Townsend's Big-eared 
Bat (Pierson et al. 1999) generally apply to many other bat species using caves and mines in the Pryor Mountains, and provide the nucleus for a comprehensive bat management plan; some of these guidelines are included in discussions of particular resources that follow.

\section{Caves}

Caves continue to be the best-documented bat habitat in the Pryor Mountains. We now have data that indicate several caves to be important summer and winter roosting habitat for multiple bat species, including Townsend's Big-eared Bat. Mystery Cave appears to be one of the largest bat hibernacula in Montana, second only to Azure Cave in the Little Rocky Mountains (Hendricks et al. 2000). At this time, however, few caves are protected from unauthorized human access; unprotected caves include several used by Townsend's Big-eared Bat.

It is difficult to know how much human visitation the more remote caves receive, and which ones might need to be considered for bat-friendly gates. Use of all-terrain vehicles makes most caves vulnerable to increased levels of recreational caving and/or vandalism. Visitor logs, similar to those at trailheads into wilderness areas, should be installed near entrances of all of the named caves appearing on maps, and routinely monitored by agency personnel. Visitor logs will provide some idea of the magnitude of visitor use, from which to base plans to gate or not. For gated caves, continue to require registration for the gate keys, but include a follow-up questionnaire that directs cavers to describe the number and location of any bats observed during their trip. The most accessible, non-vertical, caves used by Townsend's Big-eared Bat (Four Eared Bat Cave, Royce Cave) should be considered for immediate batfriendly gating. Caves used as hibernacula by Townsend's Big-eared Bat should be closed to visitors for the period 1 November - 1 May.

Caves known to be hibernacula should be visited every 4-5 years by agency biologists or competent cavers during winter or early spring, and a count of hibernating bats conducted. Summer monitoring at cave entrances should also be conducted during the same years of hibernation counts, and extended into the fall swarming period (late August-early September). These data will provide a time-series measure of year-round bat activity at these important landscape features.

\section{Mines}

Un-reclaimed mines on the southern exposures of the Pryor Mountains provide bats with important roosting and foraging habitat (Madson and Hanson 1992, Hendricks and Carlson 2001); these mines should be made inaccessible to bats to mitigate liability and safety concerns only as a last resort. Summer activity should be monitored every few years at the four mine workings mentioned below. These mines are also relatively accessible in winter, and could be entered by biologists familiar with bats and trained in mine safety, to determine the magnitude of their use as hibernacula by bats.

Survey results indicate that increased bat use in summer and winter is possible at the larger underground workings if they are protected from human disturbance with bat-friendly gates. Gates should be installed on the Dandy Mine Upper West (\#4) adit and the Marie Mine, the two most extensive workings. There is evidence of frequent and recent human entry at both mines, and both are easily accessible by all-terrain vehicles. The Dandy Mine is a Townsend's Big-eared Bat hibernaculum, and is heavily used by bats during summer, at least as a temporary night roost and source of water. The Dandy Mine Lower West (\#6) adit and CM\&M Mine East adit are suitable for bat-friendly gates, although the workings in each are less extensive and complex than in the first two workings mentioned above; each also receives an undetermined amount of human disturbance. For any mines to receive bat-friendly gates, multi-season pre-gating inventories should be conducted, followed by annual post-gating inventories for a few years, to document the effectiveness of the gating and utility of the gate design. Mines used as hibernacula by Townsend's Big-eared Bat should not be visited for the period 1 November - 1 May. 


\section{Water Sources}

Water availability in proximity to roosting sites is considered an important factor for bats (Adams 2003), especially in arid environments, although data to support this are limited. Many species appear at water sources shorty after dusk to feed and drink. Spotted Bat is known for foraging 16-50 feet (5-15 m) above ground (Nagorsen and Brigham 1993, Adams 2003), yet the only two individuals captured in the Pryor Mountains (at Layout Creek Ranger Station) were flying low over a pond (Worthington 1991a, 1991b), possibly coming down to pond level to drink. All captures of Pallid Bat in the Pryor Mountains have occurred at ponds or springs. At the Dandy Mine Upper West (\#4) adit, the most bat-active mine we netted during 2001-2003, we observed many bats drinking from the pool of standing water 60 feet beyond the portal.

Water sources at low elevation on the south and east aspects of the Pryor Mountains are few. All low-elevation springs in the Pryor Mountains should be protected from livestock and wild horse disturbance, through use of fenced exclosures; outflow channels can be run into ponds where livestock and other wildlife have access. However, creation of barriers too close together or too tall will prevent bats from gaining access to the water sources, as bats drink while in flight and need space to manuver. Vegetation overgrowing springs and their outflows, excluding bats from gaining access, should be cleared or thinned as needed. Temporary rainwater catchments could also be created, and designed in a manner that exclude livestock and wild horses but allow safe access by bats and other smaller wildlife species. Stock ponds could be modified such that a portion of them is protected from livestock disturbance; at water wells with tanks, an overflow pond with livestock exclosure could be created. Where appropriate, wells normally shut off after livestock are rotated from allotments (late in the summer) could continue to pump water into tanks and ponds, providing bats with a late season water source when none normally is found.

Periodic sampling for bats at all water sources should be undertaken to monitor bat activity at them, and to determine their use by the species of conservations concern, such as Pallid Bat, Townsend's Big-eared Bat, and Spotted Bat. Sampling at water sources could be done every few years in conjunction with a broad monitoring effort at caves and mines.

\section{Forest Management}

The way in which timbered lands are managed can have a major impact on the bats present; many species use cavities, foliage, and spaces behind loose bark, in both live and dead trees and stumps, for roosting habitat (Nagorsen and Brigham 1993, Adams 2003), and forested landscapes often are those where bats forage. Forest practices designed for the protection of cavity-nesting birds and forest hawks would benefit bats. Salvage logging activities should be designed to retain standing trees with cavities or exfoliating bark. Recommendations for Townsend's Big-eared Bat in Pierson et al. (1999) include seasonal restrictions on harvest activities and road building to avoid disturbance to known maternity colonies (JuneAugust) and hibernacula (October-May). Buffer zones around sites may need to be as much as 0.25 miles around year-round roosts, and 500 feet from roost entrances.

\section{Bridges}

Bridges provide a variety of roosting habitat for bats (Davis and Cockrum 1963, Keeley and Tuttle 1999), including sites for maternity colonies (Hendricks et al. submitted). Although bridges are relatively few in the Pryor Mountains, periodic inspection of them may reveal unsuspected roosts of several species, including Pallid Bat. Most bridge use will likely be as night roosts.

\section{Weeds}

Noxious and exotic weeds are probably only a minor consideration in the conservation and management of bats in the Pryor Mountains. Nevertheless, we documented a case where two Western Long-eared Myotis (Myotis evotis) became entangled in burdock (Arctium minus) and died as a result (Hendricks et al. 2003). Noxious weeds, especially burdock, could become prolific around water sources and other sites (such as trail corridors) where livestock trample the ground and 
promote the establishment of weeds. Use of herbicides to control weeds should be given careful consideration, and applied only locally.

\section{Conclusions}

The bat fauna of the Bull Mountains remains poorly studied and documented. Nevertheless, most species that occur in the Pryor Mountains probably are present in the Bulls; Townsend's Big-eared Bat and Spotted Bat are known to occur there. Priority management activity in the Bull Mountains should include continued inventory to identify specific features of the landscape that are important for bats. Inventory work along the Yellowstone River corridor would document the importance of this area for bats inhabiting the region between the Bull Mountains and the Pryor Mountains to the south. Because most of the Bull Mountains is private, the biggest long-term challenge to bat conservation there will be gaining the cooperation of private landholders in any comprehensive management plan.
The Pryor Mountains are a unique landscape in Montana, supporting the most diverse bat fauna in the state. Ten bat species are known to be present, another species has been reported recently, and additional species are possible. Documented species include three on the state Animal Species of Concern list (Carlson 2003): Pallid Bat, Townsend's Big-eared Bat, and Spotted Bat. Continued resource extraction and grazing issues, and increased recreational activity in the Pryor Mountains, mean the time has arrived to develop a comprehensive conservation plan for the bat fauna. The development of such a plan is a real possibility, but to be the most effective it needs to be a cooperative effort between the Bureau of Land Management and the U. S. Forest Service, National Park Service, and Crow Tribe. A conservation plan specific to the Pryor Mountains might be relative easy to create by following the framework of the state bat management plan that is currently being developed by Montana Fish, Wildlife and Parks under the guidance of Kristi DuBois (nongame coordinator). 


\section{Literature Cited}

Adams, R. A. 2003. Bats of the Rocky Mountain West. University Press of Colorado, Boulder, CO. 289 pp.

Anderson, S. H., W. A. Hubert, C. Patterson, A. J. Redder, and D. Duvall. 1987. Distribution of vertebrates of the Bighorn Canyon National Recreation Area. Great Basin Naturalist 47:512-521.

Bonnichsen, R., R. W. Graham, T. Geppert, J. S. Oliver, S. G. Oliver, D. Schnurrenberger, R. Stuckenrath, A. Tratebas, and D. E. Young. 1986. False Cougar and Shield Trap Caves, Pryor Mountains, Montana. National Geographic Research 2:276-290.

Campbell, N. F. 1978. Caves of Montana. Montana Bureau of Mines and Geology Bulletin 105. $169 \mathrm{pp}$.

Carlson, J. (Coordinator, Montana Animal Species of Concern Committee). 2003. Montana Animal Species of Concern. Montana Natural Heritage Program and Montana Fish, Wildlife and Parks, Helena, Montana. $14 \mathrm{pp}$.

Cryan, P. M., M. A. Bogan, and J. S. Altenbach. 2000. Effect of elevation on distribution of female bats in the Black Hills, South Dakota. Journal of Mammalogy 81:719725.

Davis, R., and E. L. Cockrum. 1963. Bridges utilized as day-roosts by bats. Journal of Mammalogy 44:428-430.

Dobkin, D. S., R. D. Gettinger, and M. G. Gerdes. 1995. Springtime movements, roost use, and foraging activity of Townsend's Bigeared Bat (Plecotus townsendii) in central Oregon. Great Basin Naturalist 55:315321.

Fenton, M. B. 1997. Science and the conservation of bats. Journal of Mammalogy 78:1-14.
Foresman, K. R. 2001. The wild mammals of Montana. American Society of Mammalogists, Special Publication No. 12. $278 \mathrm{pp}$.

Hayes, J. P. 2003. Habitat ecology and conservation of bats in western coniferous forests. Pp. 81-119 In Mammal community dynamics: management and conservation in the coniferous forests of western North America (C. J. Zabel and R. G. Anthony, eds.). Cambridge University Press, Cambridge, UK. 709 pp.

Hendricks, P., and J. Carlson. 2001. Bat use of abandoned mines in the Pryor Mountains. Report to the Montana Department of Environmental Quality, Mine Waste Cleanup Bureau. Montana Natural Heritage Program, Helena. 8 pp.

Hendricks, P., J. Carlson, and C. Currier. 2003. Fatal entanglement of Western Long-eared Myotis in burdock. Northwestern Naturalist 84:44-45.

Hendricks, P., D. L. Genter, and S. Martinez. 2000. Bats of Azure Cave and the Little Rocky Mountains, Montana. Canadian Field-Naturalist 114:89-97.

Hendricks, P., J. Johnson, S. Lenard, and C. Currier. Submitted. Use of a bridge for day roosting by the Hoary Bat (Lasiurus cinereus). Canadian Field-Naturalist.

Hendricks, P., and D. Kampwerth. 2001. Roost environments for bats using abandoned mines in southwestern Montana: a preliminary assessment. Report to the U.S. Bureau of Land Management. Montana Natural Heritage Program, Helena. 19 pp. 
Hoffmann, R. S., D. L. Pattie, and J. F. Bell. 1969. The distribution of some mammals in Montana. II. Bats. Journal of Mammalogy 50:737-741.

Humphrey, S. R. 1975. Nursery roosts and community diversity of Nearctic bats. Journal of Mammalogy 56:321-346.

Jones, J. K., Jr., R. P. Lampe, C. A. Spenrath, and T. H. Kunz. 1973. Notes on the distribution and natural history of bats in southeastern Montana. Occasional Papers, The Museum, Texas Tech University 15:1-12.

Keeley, B. W., and M. D. Tuttle. 1999. Bats in American bridges. Resource Publication No. 4. Bat Conservation International. Austin, TX. $41 \mathrm{p}$.

Madson, M., and G. Hanson. 1992. Bat hibernaculum search in the Pryor Mountains of south-central Montana. Montana Natural heritage Program, Helena, MT. 35 pp. + appendices.

Nagorsen, D. W., and R. M. Brigham. 1993. Bats of British Columbia. UBC Press. Vancouver, BC. 164 p.

Nesser, J. A., G. L. Ford, C. L. Maynard, and D. S. Page-Dumroese. 1997. Ecological units of the Northern Region: subsections. General Technical Report INT-GTR-369. Ogden, UT: U.S. Department of Agriculture, Forest Service, Intermountain Research Station. 88 pp.

Nicholson, A. J. 1950. A record of the Spotted Bat (Euderma maculata) for Montana. Journal of Mammalogy 31:197.

O'Shea, T. J., M. A. Bogan, and L. E. Ellison. 2003. Monitoring trends in bat populations of the United States and territories: status of the science and recommendations for the future. Wildlife Society Bulletin 31:1629.
Pierson, E. D. 1998. Tall trees, deep holes, and scarred landscapes: conservation biology of North American bats. Pp. 309-325, In Bat biology and conservation (T. H. Kunz and P. A. Racey, eds.). Smithsonian Institution Press, Washington, DC. 365 pp.

Pierson, E. D., and 14 others. 1999. Species conservation assessment and strategy for Townsend's Big-eared Bat (Corynorhinus townsendii townsendii and Corynorhinus townsendii pallescens). Idaho Conservation Effort, Idaho Department of Fish and Game, Boise, ID. 68 pp.

Priday, J., and B. Luce. 1997. Inventory of bats and bat habitat associated with caves and mines in Wyoming: completion report. Pp. 50-109, In Endangered and nongame bird and mammal investigations. Annual Completion Report, Nongame Program, Biological Services Section, Wyoming Game and Fish Department. 234 pp.

Priday, J., and B. Luce. 1999. New distributional records for Spotted Bat (Euderma maculatum) in Wyoming. Great Basin Naturalist 59:97-101.

Sheffield, S. R., J. H. Shaw, G. A. Heidt, and L. R. McClenaghan. 1992. Guidelines for the protection of bat roosts. Journal of Mammalogy 73:707-710.

Sherwin, R. E., D. Strickland, and D. S. Rogers. 2000. Roosting affinities of Townsend's Big-eared Bat (Corynorhinus townsendii) in northern Utah. Journal of Mammalogy 81:939-947.

Sherwin, R. E., W. L. Gannon, and J. S. Altenbach. 2003. Managing complex systems simply: understanding inherent variation in the use of roosts by Townsend's Big-eared Bat. Wildlife Society Bulletin 31:62-72.

Shryer, J. and D. L. Flath. 1980. First record of the Pallid Bat (Antrozous pallidus) from Montana. Great Basin Naturalist 40:115. 
Sokal, R. R., and F. J. Rohlf. 1981. Biometry, second edition. W. H. Freeman. San Francisco, CA.859 pp.

Swenson, J. E. 1970. Notes on the distribution of Myotis leibii in eastern Montana. Blue Jay 28:173-174.

Swenson, J. E., and J. C. Bent. 1977. The bats of Yellowstone County, southcentral Montana. Proceedings of the Montana Academy of Sciences 37:82-84.

Szewczak, J. M., S. M. Szewczak, M. L. Morrison, and L. S. Hall. 1998. Bats of the White and Inyo mountains of California-Nevada. Great Basin Naturalist 58:66-75.

van Zyll de Jong, C. G. 1985. Handbook of Canadian mammals. 2. Bats. National Museum of Natural Sciences. Ottawa, ON. 212 p.

Worthington, D. J. 1991a. Abundance and distribution of bats in the Pryor Mountains of south central Montana and northeastern Wyoming. Report for the Bureau of Land Management Billings Resource Area and Custer National Forest. Montana Natural Heritage Program, Helena, MT. 23 pp.

Worthington, D. J. 1991b. Abundance, distribution, and sexual segregation of bats in the Pryor Mountains of south central Montana. Master's Thesis, University of Montana, Missoula, MT. 41 pp.

Worthington, D. J., and H. N. Ross. 1990.

Abundance and distribution of bats in the Pryor Mountains of south central Montana. Report for the Bureau of Land Management Billings Resource Area and Custer National Forest. Montana Natural Heritage Program, Helena, MT. 20 pp. 


\section{Appendix A. Global/State Rank Definitions}




\section{Heritage Program Ranks}

The international network of Natural Heritage Programs employs a standardized ranking system to denote global (range-wide) and state status. Species are assigned numeric ranks ranging from 1 to 5, reflecting the relative degree to which they are "at-risk". Rank definitions are given below. A number of factors are considered in assigning ranks - the number, size and distribution of known "occurrences" or populations, population trends (if known), habitat sensitivity, and threat. Factors in a species' life history that make it especially vulnerable are also considered (e.g., dependence on a specific pollinator).

Global Rank Definitions (NatureServe 2003)

G1 Critically imperiled because of extreme rarity and/or other factors making it highly vulnerable to extinction

G2 Imperiled because of rarity and/or other factors making it vulnerable to extinction

G3 Vulnerable because of rarity or restricted range and/or other factors, even though it may be abundant at some of its locations

G4 Apparently secure, though it may be quite rare in parts of its range, especially at the periphery

G5 Demonstrably secure, though it may be quite rare in parts of its range, especially at the periphery

T1-5 Infraspecific Taxon (trinomial) - The status of infraspecific taxa (subspecies or varieties) are indicated by a "T-rank" following the species' global rank

\section{State Rank Definitions}

S1

S2

S3

S4

S5

At high risk because of extremely limited and potentially declining numbers, extent and/or habitat, making it highly vulnerable to extirpation in the state At risk because of very limited and potentially declining numbers, extent and/or habitat, making it vulnerable to extirpation in the state

Potentially at risk because of limited and potentially declining numbers, extent and/or habitat, even though it may be abundant in some areas

$4 \quad$ Uncommon but not rare (although it may be rare in parts of its range), and usually widespread. Apparently not vulnerable in most of its range, but possibly cause for long-term concern Common, widespread, and abundant (although it may be rare in parts of its range). Not vulnerable in most of its range

\section{Combination RANKS}

G\#G\# or S\#S\# Range Rank-A numeric range rank (e.g., G2G3) used to indicate uncertainty about the exact status of a taxon

\section{QUALIFIERS}

NR Not ranked this entity as a taxon at the current level is questionable; resolution of this uncertainty may result in change from a species to a subspecies or hybrid, or inclusion of this taxon in another taxon, with the resulting taxon having a lower-priority (numerically higher) conservation status rank 
Presumed Extinct-Species believed to be extinct throughout its range. Not located despite intensive searches of historical sites and other appropriate habitat, and virtually no likelihood that it will be rediscovered

Possibly Extinct-Species known from only historical occurrences, but may never-theless still be extant; further searching needed

Unrankable - Species currently unrankable due to lack of information or due to substantially conflicting information about status or trends

HYB Hybrid - Entity not ranked because it represents an interspecific hybrid and not a species

Inexact Numeric Rank-Denotes inexact numeric rank

$\mathrm{C}$

Captive or Cultivated Only - Species at present is extant only in captivity or cultivation, or as a reintroduced population not yet established

Accidental-Species is accidental or casual in Montana, in other words, infrequent and outside usual range. Includes species (usually birds or butterflies) recorded once or only a few times at a location. A few of these species may have bred on the one or two occasions they were recorded

Z

Zero Occurrences - Species is present but lacking practical conservation concern in Montana because there are no definable occurrences, although the taxon is native and appears regularly in Montana

Potential-Potential that species occurs in Montana but no extant or historic occurrences are accepted

R Reported - Species reported in Montana but without a basis for either accepting or rejecting the report, or the report not yet reviewed locally. Some of these are very recent discoveries for which the program has not yet received first-hand information; others are old, obscure reports

SYN Synonym - Species reported as occurring in Montana, but the Montana Natural Heritage Program does not recognize the taxon; therefore the species is not assigned a rank

A rank has been assigned and is under review. Contact the Montana Natural Heritage Program for assigned rank

B Breeding - Rank refers to the breeding population of the species in Montana 
Appendix B. Bats Captured or Recovered During 2001-2003 Surveys in the Pryor Mountains, Carbon County Montana 


\begin{tabular}{|c|c|c|c|c|c|c|c|}
\hline Site $^{1}$ & Date & Species $^{2}$ & $\operatorname{Sex}^{3}$ & $\mathrm{Age}^{4}$ & Weight (g) & Forearm (mm) & Reproductive Status \\
\hline 1 & 14-Jul-01 & EPFU & M & $\mathrm{A}$ & 14 & 43 & S \\
\hline 1 & 14-Jul-01 & $\mathrm{LACl}$ & $M$ & $A$ & 26.5 & 53.4 & $\mathrm{~N}$ \\
\hline 1 & 8-Aug-02 & ANPA & $\mathrm{F}$ & $A$ & 20.5 & 55.1 & $\mathrm{~L}$ \\
\hline 1 & 8-Aug-02 & MYEV & $\mathrm{M}$ & $A$ & 6.8 & 40.1 & $\mathrm{~N}$ \\
\hline 1 & 9-Sep-03 & $\mathrm{MYCl}$ & $M$ & $A$ & 4.5 & 32.9 & $\mathrm{~S}$ \\
\hline 1 & 9-Sep-03 & $\mathrm{MYCl}$ & $U$ & $U$ & & & $U$ \\
\hline 1 & 9-Sep-03 & MYVO & M & A & 8 & 38.2 & $\mathrm{~N}$ \\
\hline 2 & 15-Jul-01 & MYEV & $M$ & A & 6.5 & 40.4 & $\mathrm{~N}$ \\
\hline 2 & 15-Jul-01 & MYEV & $M$ & $A$ & 6.5 & 38 & $\mathrm{~N}$ \\
\hline 2 & 15-Jul-01 & MYVO & $M$ & $A$ & 8 & 39.3 & $\mathrm{~N}$ \\
\hline 2 & 15-Jul-01 & MYEV & $M$ & $A$ & 7 & 39 & $\mathrm{~N}$ \\
\hline 2 & 15-Jul-01 & $\mathrm{MYCl}$ & $\mathrm{F}$ & $A$ & 4.5 & 31.2 & $\mathrm{~N}$ \\
\hline 2 & 15-Jul-01 & MYLU & $\mathrm{M}$ & A & 7 & 37.7 & $\mathrm{~N}$ \\
\hline 2 & 15-Jul-01 & MYEV & $\mathrm{M}$ & A & 6.5 & 39.2 & $\mathrm{~N}$ \\
\hline 2 & 15-Jul-01 & MYEV & $M$ & A & 6.5 & 39.1 & $\mathrm{~N}$ \\
\hline 2 & 15-Jul-01 & MYEV & $\mathrm{M}$ & $A$ & 6.5 & 38.4 & $\mathrm{~N}$ \\
\hline 2 & 15-Jul-01 & MYEV & $M$ & A & 6.5 & 37.8 & $\mathrm{~N}$ \\
\hline 2 & 15-Jul-01 & MYLU & $\mathrm{M}$ & $A$ & 7.5 & 37.1 & $\mathrm{~N}$ \\
\hline 2 & 15-Jul-01 & MYLU & $M$ & $A$ & 7 & 39.8 & $\mathrm{~N}$ \\
\hline 2 & 15-Jul-01 & MYEV & $M$ & $A$ & 7 & 38.3 & $\mathrm{~N}$ \\
\hline 2 & 15-Jul-01 & MYEV & $M$ & A & 7.5 & 39.9 & $\mathrm{~N}$ \\
\hline 2 & 15-Jul-01 & MYLU & $M$ & $A$ & 7 & 37.5 & $\mathrm{~N}$ \\
\hline 2 & 15-Jul-01 & MYLU & $\mathrm{M}$ & $A$ & 7.5 & 38.2 & $\mathrm{~N}$ \\
\hline 2 & 15-Jul-01 & MYLU & $M$ & $A$ & 7 & 36.6 & $\mathrm{~N}$ \\
\hline 2 & 15-Jul-01 & MYEV & $M$ & $A$ & 8 & 39.5 & $\mathrm{~N}$ \\
\hline 3 & 16-Jul-01 & MYEV & $M$ & $A$ & 6 & 38.3 & $\mathrm{~N}$ \\
\hline 3 & 16-Jul-01 & $\mathrm{MYCl}$ & $M$ & $A$ & 4.5 & 32.1 & $\mathrm{~N}$ \\
\hline 3 & 16-Jul-01 & MYEV & $M$ & A & 5.5 & 37.1 & $\mathrm{~N}$ \\
\hline 3 & 16-Jul-01 & MYEV & $M$ & $A$ & 6.5 & 38.6 & $\mathrm{~N}$ \\
\hline 3 & 16-Jul-01 & MYEV & $M$ & A & & & $U$ \\
\hline 3 & 16-Jul-01 & MYEV & $\mathrm{F}$ & $A$ & 7 & 39.5 & $\mathrm{~N}$ \\
\hline 3 & 16-Jul-01 & MYEV & $F$ & A & 6.5 & 40 & $\mathrm{~N}$ \\
\hline 3 & 16-Jul-01 & MYEV & $M$ & A & & & $U$ \\
\hline 3 & 16-Jul-01 & MYEV & $F$ & A & 7.5 & 40.2 & $\mathrm{~N}$ \\
\hline 3 & 16-Jul-01 & MYEV & $M$ & A & & & $U$ \\
\hline 3 & 16-Jul-01 & MYEV & $\mathrm{F}$ & A & 7 & 39.5 & $\mathrm{~N}$ \\
\hline 3 & 16-Jul-01 & MYEV & $F$ & $A$ & 8 & 39.7 & $\mathrm{~N}$ \\
\hline 3 & 16-Jul-01 & MYEV & $\mathrm{F}$ & $A$ & 7 & 41.4 & $\mathrm{~N}$ \\
\hline 3 & 16-Jul-01 & MYEV & $M$ & $A$ & 7 & 37.7 & $\mathrm{~N}$ \\
\hline 3 & 16-Jul-01 & MYEV & $F$ & A & 9 & 40.4 & $\mathrm{~N}$ \\
\hline 3 & 6-Aug-02 & MYEV & $\mathrm{F}$ & A & 6.5 & 39.1 & $\mathrm{~L}$ \\
\hline 3 & 6-Aug-02 & MYEV & $\mathrm{M}$ & $A$ & 6 & 39 & $S$ \\
\hline 3 & 6-Aug-02 & MYEV & $\mathrm{F}$ & A & 6.8 & 38.9 & $\mathrm{~L}$ \\
\hline 3 & 6-Aug-02 & MYEV & $\mathrm{F}$ & A & 6.6 & 40 & $\mathrm{~N}$ \\
\hline 3 & 6-Aug-02 & MYEV & $M$ & A & 5.6 & 39.4 & $S$ \\
\hline 3 & 6-Aug-02 & сото & $\mathrm{F}$ & $A$ & 10.6 & 44.7 & $\mathrm{~N}$ \\
\hline
\end{tabular}




\begin{tabular}{|c|c|c|c|c|c|c|c|}
\hline Site $^{1}$ & Date & Species $^{2}$ & $\operatorname{Sex}^{3}$ & Age $^{4}$ & Weight (g) & Forearm (mm) & Reproductive Status \\
\hline 4 & 7-Aug-02 & $\mathrm{MYCl}$ & $\mathrm{M}$ & $A$ & 4.3 & 32.2 & $S$ \\
\hline 4 & 7-Aug-02 & сото & $\mathrm{F}$ & $A$ & 10.1 & 43.9 & $\mathrm{~N}$ \\
\hline 4 & 7-Aug-02 & сото & $\mathrm{F}$ & $A$ & 9.8 & 43.4 & $\mathrm{~N}$ \\
\hline 4 & 7-Aug-02 & $\mathrm{MYCl}$ & M & $A$ & 4.4 & 32.5 & $S$ \\
\hline 4 & 7-Aug-02 & $\mathrm{MYCl}$ & $M$ & $A$ & 4.4 & 31.5 & $\mathrm{~S}$ \\
\hline 4 & 7-Aug-02 & соTO & $\mathrm{F}$ & $A$ & 10.4 & 46.4 & $\mathrm{~N}$ \\
\hline 4 & 7-Aug-02 & $\mathrm{MYCl}$ & M & $A$ & 3.8 & 29.8 & $S$ \\
\hline 4 & 7-Aug-02 & $\mathrm{MYCl}$ & $M$ & $A$ & 4.9 & 32.8 & $S$ \\
\hline 5 & 25-Jul-01 & $\mathrm{MYCl}$ & $M$ & $A$ & 4 & 32.6 & $\mathrm{~N}$ \\
\hline 5 & 25-Jul-01 & MYEV & $\mathrm{F}$ & $A$ & 6.2 & 37.6 & L \\
\hline 5 & 25-Jul-01 & MYEV & $\mathrm{F}$ & $A$ & 6.2 & 34.8 & L \\
\hline 5 & 25-Jul-01 & MYEV & $M$ & $A$ & 7.1 & 37.5 & $\mathrm{~N}$ \\
\hline 5 & 25-Jul-01 & MYEV & $\mathrm{F}$ & A & 6.5 & 38 & L \\
\hline 5 & 25-Jul-01 & MYEV & $M$ & $A$ & 6.8 & 37.6 & $\mathrm{~N}$ \\
\hline 5 & 25-Jul-01 & $\mathrm{MYCl}$ & $M$ & $\mathrm{~J}$ & 4.3 & 31.7 & $\mathrm{~N}$ \\
\hline 5 & 25-Jul-01 & $\mathrm{MYCl}$ & $\mathrm{M}$ & A & 5 & 31.9 & $\mathrm{~N}$ \\
\hline 5 & 25-Jul-01 & EPFU & $\mathrm{M}$ & $A$ & 18.6 & 48.8 & $\mathrm{U}$ \\
\hline 5 & 4-Sep-01 & $\mathrm{MYCl}$ & $M$ & $A$ & 5.1 & 31.9 & $S$ \\
\hline 5 & 4-Sep-01 & MYEV & $\mathrm{M}$ & $A$ & 6 & 38 & $S$ \\
\hline 5 & 4-Sep-01 & $\mathrm{MYCl}$ & $M$ & $A$ & 5 & 33 & $S$ \\
\hline 5 & 4-Sep-01 & MYEV & $M$ & A & & & $S$ \\
\hline 5 & 4-Sep-01 & $\mathrm{MYCl}$ & $M$ & $A$ & & & $S$ \\
\hline 5 & 4-Sep-01 & EPFU & $\mathrm{F}$ & $A$ & & & $U$ \\
\hline 5 & 4-Sep-01 & $\mathrm{MYCl}$ & $\mathrm{M}$ & $A$ & & & $S$ \\
\hline 5 & 4-Sep-01 & $\mathrm{MYCl}$ & $M$ & $A$ & 4.5 & 32 & $S$ \\
\hline 5 & 4-Sep-01 & EPFU & $M$ & $A$ & 18.5 & 45.2 & $S$ \\
\hline 5 & 4-Sep-01 & $\mathrm{MYCl}$ & $\mathrm{M}$ & $A$ & 5.5 & 32.5 & $S$ \\
\hline 5 & 4-Sep-01 & $\mathrm{MYCl}$ & $M$ & $A$ & 6 & 32.5 & $S$ \\
\hline 5 & 4-Sep-01 & EPFU & M & $A$ & & & $S$ \\
\hline 5 & 4-Sep-01 & $\mathrm{MYCl}$ & $\mathrm{F}$ & $A$ & & 34.5 & $U$ \\
\hline 5 & 4-Sep-01 & $\mathrm{MYCl}$ & $\mathrm{M}$ & $A$ & & & $U$ \\
\hline 5 & 4-Sep-01 & EPFU & $M$ & $A$ & & & $S$ \\
\hline 5 & 4-Sep-01 & $\mathrm{MYCl}$ & $\mathrm{M}$ & $A$ & & 32.3 & $S$ \\
\hline 5 & 4-Sep-01 & $\mathrm{MYCl}$ & $M$ & $A$ & & 31.2 & $S$ \\
\hline 5 & 4-Sep-01 & $\mathrm{MYCl}$ & $M$ & $A$ & & 32.8 & $S$ \\
\hline 5 & 4-Sep-01 & $\mathrm{MYCl}$ & $M$ & $A$ & & 31.6 & $S$ \\
\hline 5 & 4-Sep-01 & MYEV & $M$ & $A$ & & 37.9 & $S$ \\
\hline 5 & 4-Sep-01 & EPFU & $\mathrm{F}$ & $A$ & & 45.5 & $U$ \\
\hline 5 & 4-Sep-01 & MYEV & $\mathrm{F}$ & $A$ & & 40 & $U$ \\
\hline 5 & 4-Sep-01 & EPFU & $\mathrm{F}$ & $A$ & & 45.3 & $U$ \\
\hline 5 & 4-Sep-01 & MYEV & $M$ & $A$ & 6 & 39.2 & $S$ \\
\hline 5 & 4-Sep-01 & $\mathrm{MYCl}$ & $M$ & $A$ & 4 & 32.4 & $S$ \\
\hline 5 & 4-Sep-01 & EPFU & $M$ & $A$ & & 47 & $S$ \\
\hline 5 & 4-Sep-01 & MYEV & $M$ & $A$ & 7.5 & 38.3 & $S$ \\
\hline 5 & 5-Sep-01 & MYEV & $\mathrm{F}$ & $A$ & 7 & 38.5 & $P$ \\
\hline 5 & 5-Sep-01 & MYEV & M & $A$ & 8.2 & 40.4 & $S$ \\
\hline
\end{tabular}




\begin{tabular}{|c|c|c|c|c|c|c|c|}
\hline Site $^{1}$ & Date & Species $^{2}$ & $\operatorname{Sex}^{3}$ & Age $^{4}$ & Weight (g) & Forearm (mm) & Reproductiv \\
\hline 5 & 5-Sep-01 & MYEV & $M$ & $A$ & 7.2 & 39 & $S$ \\
\hline 5 & 5-Sep-01 & MYEV & $M$ & $A$ & 7.4 & 38 & $S$ \\
\hline 5 & 9-Aug-02 & MYEV & $\mathrm{F}$ & $A$ & 5.8 & 36.8 & $L$ \\
\hline 5 & 9-Aug-02 & MYVO & $M$ & $A$ & 7.5 & 39.4 & $S$ \\
\hline 5 & 9-Aug-02 & MYEV & $F$ & $A$ & 5.7 & 38.3 & $L$ \\
\hline 5 & 9-Aug-02 & MYEV & $M$ & $A$ & 6.1 & 39.9 & $S$ \\
\hline 5 & 9-Aug-02 & MYEV & $M$ & $A$ & & & $S$ \\
\hline 5 & 9-Aug-02 & MYEV & $\mathrm{F}$ & $A$ & & & $\mathrm{~L}$ \\
\hline 5 & 9-Aug-02 & MYVO & $M$ & $A$ & & & $S$ \\
\hline 5 & 9-Aug-02 & MYEV & $\mathrm{F}$ & $A$ & & & $\mathrm{~L}$ \\
\hline 5 & 9-Aug-02 & MYEV & $\mathrm{F}$ & $A$ & & & $\mathrm{~L}$ \\
\hline 5 & 9-Aug-02 & MYEV & $M$ & $A$ & & & $S$ \\
\hline 5 & 9-Aug-02 & MYVO & $M$ & $A$ & & & $S$ \\
\hline 5 & 9-Aug-02 & MYVO & $\mathrm{F}$ & $A$ & & & $\mathrm{~L}$ \\
\hline 5 & 9-Aug-02 & MYEV & $\mathrm{F}$ & $A$ & & & $\mathrm{~L}$ \\
\hline 5 & 9-Aug-02 & MYVO & $M$ & $A$ & & & $S$ \\
\hline 5 & 9-Aug-02 & MYVO & $M$ & $A$ & 5.2 & 37.3 & $S$ \\
\hline 5 & 9-Aug-02 & MYEV & $\mathrm{F}$ & $A$ & 6 & 40.4 & $\mathrm{~N}$ \\
\hline 5 & 9-Aug-02 & MYEV & $F$ & $A$ & & & $L$ \\
\hline 5 & 9-Aug-02 & MYEV & $M$ & $A$ & 6.4 & 38.8 & $S$ \\
\hline 5 & 9-Aug-02 & MYEV & $\mathrm{F}$ & $A$ & 5.6 & 38.7 & $\mathrm{~N}$ \\
\hline 5 & 9-Aug-02 & $\mathrm{MYCl}$ & $M$ & $A$ & 4.5 & 32.5 & $S$ \\
\hline 5 & 9-Aug-02 & MYEV & $M$ & $A$ & 5.5 & 37 & $\mathrm{~N}$ \\
\hline 5 & 9-Aug-02 & MYEV & $M$ & $A$ & 7 & 36.5 & $S$ \\
\hline 5 & 9-Aug-02 & MYEV & $\mathrm{F}$ & $A$ & 6.4 & 38 & $\mathrm{~L}$ \\
\hline 5 & 9-Aug-02 & MYVO & $M$ & $A$ & 7.3 & 39.9 & $S$ \\
\hline 5 & 9-Aug-02 & MYEV & $F$ & $A$ & 7.5 & 38.4 & $L$ \\
\hline 5 & 9-Aug-02 & MYEV & $\mathrm{F}$ & $A$ & 7.3 & 38.7 & $L$ \\
\hline 5 & 9-Aug-02 & MYEV & $M$ & $A$ & 5.9 & 38.1 & $\mathrm{~N}$ \\
\hline 5 & 9-Aug-02 & MYEV & $\mathrm{F}$ & $A$ & 6.6 & 38.9 & $\mathrm{~L}$ \\
\hline 5 & 9-Aug-02 & MYEV & $\mathrm{F}$ & $A$ & 6.6 & 40.7 & $\mathrm{~N}$ \\
\hline 5 & 9-Aug-02 & MYEV & $\mathrm{F}$ & $A$ & 6.8 & 38.2 & $\mathrm{~L}$ \\
\hline 5 & 9-Aug-02 & MYEV & $F$ & $A$ & 6.2 & 40.3 & $\mathrm{~N}$ \\
\hline 5 & 9-Aug-02 & MYEV & $M$ & $A$ & 6.6 & 37.9 & $\mathrm{~N}$ \\
\hline 5 & 9-Aug-02 & MYEV & $\mathrm{F}$ & $A$ & 6.9 & 38.4 & $L$ \\
\hline 5 & 9-Aug-02 & MYEV & $M$ & $A$ & 6 & 38.7 & $\mathrm{~N}$ \\
\hline 6 & 25-Jul-01 & EPFU & $\mathrm{M}$ & $A$ & 16.5 & 43.8 & $\mathrm{~N}$ \\
\hline 6 & 25-Jul-01 & EPFU & $M$ & $A$ & 18 & 46.7 & $\mathrm{~N}$ \\
\hline 6 & 25-Jul-01 & EPFU & $M$ & $A$ & 17 & 47.5 & $\mathrm{~N}$ \\
\hline 6 & 9-Aug-02 & MYEV & $U$ & $A$ & & 40.1 & $U$ \\
\hline 7 & 27-Jul-01 & $\mathrm{MYCl}$ & $M$ & $A$ & 4 & 31.2 & $S$ \\
\hline 8 & 24-Jul-01 & $\mathrm{MYCl}$ & $M$ & $A$ & 4 & 31.7 & $U$ \\
\hline 8 & 24-Jul-01 & EPFU & $M$ & $A$ & 18 & 49.5 & $U$ \\
\hline 9 & 28-Jul-01 & $\mathrm{MYCl}$ & $M$ & $A$ & 4.2 & 32.4 & $U$ \\
\hline 9 & 28-Jul-01 & $\mathrm{MYCl}$ & $M$ & $A$ & 4.4 & 30.5 & $S$ \\
\hline
\end{tabular}




\begin{tabular}{|c|c|c|c|c|c|c|c|}
\hline Site $^{1}$ & Date & Species $^{2}$ & $\operatorname{Sex}^{3}$ & $\mathrm{Age}^{4}$ & Weight (g) & Forearm (mm) & Reproductive Status \\
\hline 10 & 28-Aug-02 & MYEV & $\mathrm{F}$ & $A$ & 6.8 & 38.1 & $\mathrm{~N}$ \\
\hline 10 & 28-Aug-02 & MYEV & $\mathrm{F}$ & A & 7.5 & 39.7 & $P$ \\
\hline 10 & 28-Aug-02 & MYEV & $\mathrm{F}$ & A & 7.7 & 38.7 & $\mathrm{~N}$ \\
\hline 10 & 28-Aug-02 & MYEV & $\mathrm{F}$ & A & 7.7 & 39.9 & $\mathrm{P}$ \\
\hline 11 & 28-Aug-02 & MYEV & $U$ & A & & & $U$ \\
\hline 11 & 28-Aug-02 & MYEV & $U$ & A & & & $U$ \\
\hline 12 & 10-Sep-03 & СОTO & M & A & 10 & 44.4 & S \\
\hline 12 & 10-Sep-03 & соTO & $\mathrm{F}$ & A & 12 & 46.2 & $\mathrm{P}$ \\
\hline 12 & 11-Sep-03 & сото & M & A & 10.5 & 46 & $S$ \\
\hline
\end{tabular}

${ }^{1}$ (1) Gyp Spring, (2) Mystery Cave, (3) Royce Cave, (4) Four Eared Bat Cave, (5) Dandy Mine Upper West Adit (\#4), (6) Dandy Mine Upper West Adit (\#5), (7) Dandy Mine Lower West Adit (\#6), (8) Marie Mine, (9) Robert's Incline Mine, (10) Bear Canyon Road Stock Pond, (11) Bear Canyon, (12) Bear Canyon BLM Campground.

${ }^{2}$ ANPA (Pallid Bat: Antrozous pallidus), COTO (Townsend's Big-eared Bat: Corynorhinus townsendii), EPFU (Big Brown Bat: Eptesicus fuscus), LACI (Hoary Bat: Lasiurus cinereus), MYCI (Western Small-footed Myotis: Myotis ciliolabrum), MYEV (Western Long-eared Myotis: Myotis evotis), MYLU (Little Brown Myotis: Myotis lucifugus), MYVO (Long-legged Myotis: Myotis volans).

${ }^{3} \mathrm{M}=$ male, $\mathrm{F}=$ female, $\mathrm{U}=$ unknown.

${ }^{4} \mathrm{~A}=$ adult, $\mathrm{J}=$ juvenile, $\mathrm{U}=$ unknown.

${ }^{5}$ Males: $\mathrm{N}=$ non-scrotal, $\mathrm{S}=$ scrotal, $\mathrm{U}=$ undetermined; Females: $\mathrm{N}=$ non-lactating, $\mathrm{L}=$ lactating, $\mathrm{P}=$ post-lactating, $\mathrm{U}=$ undetermined. 